\title{
A GENDER-FOCUSED MACRO- MICRO ANALYSIS OF THE POVERTY IMPACTS OF TRADE LIBERALIZATION IN SOUTH AFRICA $^{*}$
}

\author{
John Cockburn, Ismael Fofana, Bernard Decaluwe, \\ Ramos Mabugu and Margaret Chitiga
}

\begin{abstract}
Despite the general presumption in favor of trade liberalization, the question of how to implement it in a way to ensure equitable income distribution and sustainable poverty alleviation in developing countries is at the core of the current trade debate. We build a macroeconomic framework that integrates both market and non-market activities, while distinguishing male and female workers throughout, in order to evaluate impacts of tariffs elimination on men and women in South Africa. Our study
\end{abstract}

\footnotetext{
*This work emanates from the medium-term sub-programme (2001-2005) being implemented by the African Centre for Gender and Development (ACGD) of the United Nations Economic Commission for Africa (ECA). This work also benefited from funding from the Poverty and Economic Policy (PEP) Research Network, financed by the International Development Research Centre (IDRC).
} 
reveals a strong gender bias against women with a decrease in their labor market participation, while men participate more in the market economy. This strong result is due to the fact that female workers are concentrated in contracting sectors that were initially among the protected sectors and that benefit little from the fall in input prices. In contrast, male workers are more concentrated in the expanding export-intensive sectors. Female labor market participation drops particularly for Black African women, as they are more concentrated in contracting sectors. As male labor market participation and real wages increase more than for their female counterparts, their income share increases within the household. Women continue to suffer nonetheless from a heavy time use burden given their increased domestic work with trade liberalization.

\section{INTRODUCTION}

Over the past decade, developing countries especially in Sub-Saharan Africa have committed themselves to meeting targets in various international and bilateral agreements including the millennium development goals (MDGs). Many countries have implemented policy reforms aimed at achieving these goals. These policy reforms, including trade liberalization, will have significant repercussions on the economy of these countries and on income distribution and poverty reduction. Although the principal argument in favor of openness to trade has been the benefit brought to all nations, its partisans recognize that it creates winners and losers in all countries. The problem of the distribution of gains from trade in the developing countries, where national income is already unequally distributed, is at the core of the current trade debate.

Gender poverty and inequality has become an important issue in developing countries. Many studies show that, compared to men, women are more vulnerable to chronic poverty because of gender inequalities in the distribution of income, access to productive inputs such as credit, asset management and labor market conditions. Several other studies have focused on a variety of gender issues, including the impact of trade liberalization on gender inequalities. Most of these studies ${ }^{1}$ note a significant increase in female labor market participation during the last decade, corresponding to the period of liberalization in the majority of the developing countries. The feminization of work in export sectors was found to be stronger in the industrial sector and semi-industrialized economies, than in agricultural sectors economies. In semiindustrialized countries, some reservations have been expressed about the welfare impacts, mostly concerning the conditions under which female 
work grows. In agricultural economies, many studies ${ }^{2}$ mention that market opportunities benefit men more than women, because of the difficulties for women to access productive assets (loans, land, new technologies, knowledge, etc.).

Recently, gendered macroeconomic models ${ }^{3}$ have been used to analyze the economy-wide impact of trade liberalization on male and female welfare. These studies conclude that trade liberalization expands female work and income more than their male counterparts in the economies analyzed. Although, the expansion of female market work is seen as enhancing their negotiating power within the household, it could constitute for them a burden if there is not an equivalent reduction in their domestic work. Its perverse effects on female leisure and domestic work leave some skeptical of its benefits for women, children and other household members.

Fiscal policy is a key policy instrument in influencing men and women's welfare and their prospects for economic empowerment. It can contribute to narrowing or widening gender gaps in time use, incomes, health, education, nutrition, etc. There is also increasing concern about how gender inequality can constrain the outcomes of macroeconomic policy. Recent studies ${ }^{4}$ show that economic reforms with decreased incentives can reduce women's output or restrict access to education, and thus hinder women's ability to develop their human resources. They also observe that ignoring household non-market work may affect macroeconomic outcomes by constraining labor mobility and the supply response, as well as affecting the demand for close market substitutes to home produced commodities. ${ }^{5}$ Therefore, interactions between male and female work on the one hand, and market and non-market activities on the other hand, may play key roles in policy impact analysis.

Therefore, the analysis of the impact of trade reform policy on income distribution and poverty reduction in South Africa, and its differentiated impacts on women and men is of crucial importance.

Conventional economics and most economic statistics ignore the enormous volume of unpaid work and the undeniably valuable output of services by the household or "care" economy. Households devote a large proportion of their time to produce "home" commodities, which can neither be purchased nor sold on the market and which, therefore, are consumed entirely by the household themselves. Although, many of these commodities have their equivalents in the market economy, economics is generally blind to the unpaid work and production of women (and men) within households.

Advances in economic theory have stressed that important productive activities occur within the household, and that more attention should be devoted 
to distinguishing domestic work activities from leisure activities, as it is not likely that home production and leisure activities will be affected in the same way by changes in technology, wage rates or socioeconomic variables.

Although these gender-related development issues have prompted serious debate, the absence of appropriate gender-focused macroeconomic analytical tools has prevented quantitative analysis. A related constraint is the inadequate data and statistical indicators for effective gender-sensitive policy-making, monitoring and evaluation. ${ }^{6}$

We address this deficiency by developing a gender-focused Computable General Equilibrium (CGE) for the South African economy that distinguishes male and female workers throughout, as well as breaking down market and nonmarket activities. This approach allows us to evaluate impacts of trade liberalization on male and female time allocation between work (at the market and at home) and leisure, as well as on household welfare. CGE models are powerful tools to capture, in a general equilibrium framework, all direct and indirect effects of macroeconomic shocks (wherever the shock occurs in the economy) on sectoral production and factor demands.

\section{OVERVIEW OF SOUTH AFRICAN CHARACTERISTICS AND POLICY ON TRADE, POVERTY AND GENDER ISSUES}

\subsection{International Trade}

South Africa was reintegrated into the world economy following a credible transition to democracy symbolized by the elections in 1994. The new South African government immediately adopted the Reconstruction and Development Programme (RDP), which set the broad framework of the new government's economic and social policy. This was followed in 1996 by the launching of the Growth, Employment and Redistribution (GEAR) programme, which defined policy instruments and objectives for the five years until 2001. The pace of trade liberalization quickened after South Africa became a signatory to the Marrakech Agreement. Initial progress in rationalizing the very complex tariff regime and lowering the overall level of nominal and effective protection was relatively fast. Between 1990 and 1999, the number of tariff lines was reduced from 12,500 in 200 tariff bands to 7,743 in only 47 tariff bands. In fact, if the 
Table 1. Reform of South African Tariffs.

\begin{tabular}{lcccc}
\hline & $\begin{array}{c}\text { All Rates } \\
(1990)\end{array}$ & $\begin{array}{c}\text { All Rates } \\
(1996)\end{array}$ & $\begin{array}{c}\text { All Rates } \\
(1999)\end{array}$ & $\begin{array}{c}\text { Positive Rates } \\
(1999)\end{array}$ \\
\hline Number of lines & 12500 & 8250 & 7743 & 2463 \\
Number of bands & 200 & 49 & 47 & 45 \\
Minimum rate (\%) & 0 & 0 & 0 & 1 \\
Maximum rate (\%) & 1389 & 61 & 55 & 55 \\
Unweighted mean rate (\%) & 27.5 & 9.5 & 7.1 & 16.5 \\
Standard deviation (\%) & n.a. & n.a. & 10.0 & 8.6 \\
Coefficient of variation (\%) & 159.8 & 134.0 & 140.3 & 52.2 \\
\hline
\end{tabular}

Source: Lewis (2001).

numerous cases of zero tariffs are ignored, the number of tariff lines had been reduced to fewer than 2,500 by 1999 . At the same time, the maximum existing tariff has been reduced from almost 1,400 to 55 percent and the average economy-wide tariff fell from 28 to 7.1 percent (Table 1).

The aggregate response of trade to liberalization has been quite dramatic. The average annual growth rate of the trade ratio, as measured by the sum of export and import values to GDP (in current prices), was 5.5 percent between 1993 and 1996, 0.8 percent between 1997 and 1999 and 9.8 percent between 2000 and 2002 (Davies \& van Seventer, 2003). Closer inspection shows that the trade ratio started to grow in 1992, perhaps reflecting the post-apartheid reintegration. The slowdown in 1997-1999 was probably related to the Asian crisis, but may also reflect the ending of the initial impetus provided by the ending of apartheid. The acceleration after 1999 likely reflects both world recovery and domestic liberalization policies starting to make an impact.

A broad look at the performance of exports in the apartheid, transition and liberalized periods suggests that the reforms may have stimulated export growth. During the pre-democracy period (1981-1990), the value of exports declined by an average of 2.6 percent. Between 1991 and 1996, export growth averaged 6.4 percent per year. During the liberalized period (1997-2002), exports grew by only 3.7 percent per annum. However, this latter figure masks a sharp downturn in the mining sector in recent years. As to the composition of exports, the share of manufacturing products increased from 41.2 percent in 1991-1996 to 53.3 percent in 1997-2001, while the share of mining diminished from 42.3 percent in 1991-1996 to 26.9 percent in 1997-2001. Gold, the main South African export, still accounted for more than 20 percent of total exports in 
1997-2001, down from more than 35 percent in 1991-1996 (TIPS, 2002). The performance of imports in the transition and liberalized periods suggests that the reforms may have also stimulated import growth, albeit marginally. TIPS (2002) shows that imports grew by an average of 11.7 percent in the transition period between 1991 and 1996, but grew by only 0.1 percent between 1997 and 2001. The relatively low growth in the latter years is puzzling given that tariffs were falling in this period, although GDP growth was muted. Imports, just as exports, are dominated by manufactured and mining products, accounting for over 86 percent of imports over the two periods.

In terms of trade competitiveness, South Africa has on average experienced a 50 percent decline in terms of trade over the two periods, with the exclusion of gold (Ndlela \& Nkala, 2003). Although the terms of trade inclusive of gold have increased by about 20 percent during the same period, the overall decline in the terms of trade reflects a critical weakness in the structure of the country's trade composition. Like many developing countries, a large proportion of exports consist of unprocessed raw materials with, in the case of South Africa, the mining industry contributing the greatest proportion to the country's total exports. The proportion of manufactured goods in exports has however experienced a significant rise, with a higher proportion of raw materials being processed before export. Major export commodities are gold, diamonds, platinum, wool, sugar, manganese and chrome ores, asbestos, atomic energy materials and base minerals such as coal, antimony, copper and iron ore. Exports of chemicals, metal products, machinery, transport equipment and manufactured goods have increased, particularly to Africa, in recent years.

\subsection{Income Distribution and Poverty}

South Africa has one of the worst income distributions in the world. The Gini coefficient, which measures the degree of income inequality, was 0.56 in 1995 and 0.57 in 2000, implying that the income distribution has also been getting worse across the country. In addition, the Gini coefficient not only takes high values for the country as a whole, but also for individual population categories, suggesting a high degree of inequality within each major ethnic group. The Gini coefficient is higher for Africans than for Whites. More significantly, according to ILO (1999), income distribution within population groups worsened between 1990 and 1995 while inequality decreased between groups. This may reflect the fact that the end of apartheid-based discrimination has created new employment 
opportunities for highly skilled Africans. Income is also unevenly distributed among rural and urban areas.

There is general agreement that poverty has grown worse since liberalization. The World Bank (1999) notes that extreme poverty is concentrated mainly in rural areas, where over 75 percent of the households cannot meet their minimum food requirements. In urban areas poverty is much less acute, with only about 10 percent of the households below the poverty line. The same study argues that poverty has a strong gender dimension, showing that female-headed households have a 50 percent higher poverty rate than male-headed households. In addition, unemployment figures have shown that females suffer more from unemployment than males. Although no concrete evidence is available, there is a general consensus that this pattern has persisted over time. The UNDP (2000) gives the rate of poverty as 45 percent. This is despite the fact that South Africa is classified as an upper middle-income country. Poverty differs greatly by region and by race, with the majority of the poor being Black Africans. According to Klasen and Woolard (1998), there is a strong correlation between unemployment and poverty. They estimate that the unemployment rate among the 20 percent poorest households is 53 percent compared to 4 percent in the case of the richest 20 percent households. The problem is not restricted to persons with low levels of formal education. Although education reduces the likelihood of unemployment, rates are extremely high amongst African women, irrespective of whether or not they have completed secondary education. It should be noted, however, that significant differences exist in the quality of education that has been provided to different population groups. This is a legacy of deliberate discrimination under the apartheid system. Only tertiary education seems to substantially reduce the risk of unemployment for both men and women.

\subsection{Gender in the South African Economy}

Male and female time allocation is presented in Fig. 1. At the national level, men are more active in the labor market than women, contributing roughly 60 percent of total market labor. Women, meanwhile, perform more than 75 percent of domestic unpaid work.

Looking at employment in formal versus informal sectors, we note that, in broad terms, women are concentrated in informal services and trade. In 1995, 33 percent of economically active African women were own account 


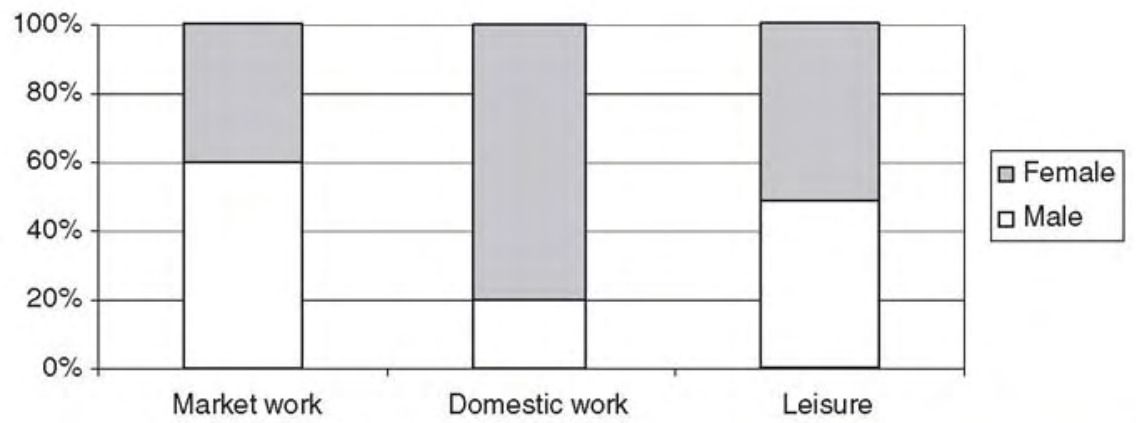

Fig. 1. Gender Time Allocation in 2000. Source: Statistics South Africa (2001b).

workers compared to 6 percent of men. Women are generally concentrated within the low profit activities, generally earn less and tend to have smaller activities in the informal sector (Baden, Hasim, \& Meintjes, 1998). Although in general more women than men work in the informal sector, the sectoral distribution of men and women in the informal sector as well as the occupations are very similar to the formal sector. Valodia (2000) gives more corroborating evidence validating this.

A broad look at the participation of women in formal employment in the apartheid, transition and liberalized periods suggests that female participation rates have been on a general increase. Standing, Sender, and Weeks (1996) show that this trend started in the apartheid era, with female labor force participation increasing from 23 percent to 41 percent between 1960 and 1991. According to the World Bank (2002), female labor force as a percentage of total labor force has moved from 37 percent in 1990 to 38 percent in 2000. According to Casale and Posel (2002), the post-apartheid period from 1995 to 1999 witnessed a continued feminization of the labor force in South Africa. In 1995, 38 percent of all females between the ages of 15 and 65 were either working or actively looking for work. By 1999, this had increased to 47 percent.

A gender segregated labor market in South Africa may be explained by discrimination against women in education and training during the apartheid period. However, post-apartheid primary and secondary enrolment and literacy rates suggest a dramatic improvement in these indicators for women (World Bank, 2004). Men and women tend to work in different sectors. Some sectors are male-intensive (i.e. mining, food, beverage and tobacco, heavy manufacturing and construction), while others are female-intensive (i.e. textile, private services). Women are engaged primarily in tertiary activities, while men 
are spread throughout primary and secondary sectors. This trend between men and women has not changed much, as seen in the 2001 census data represented in Fig. 2.

As shown in Table 2, unemployment rates for women are much higher than for men. This is true for all population groups, especially in urban areas where unemployment was estimated at over 28 percent for women, compared to 24.1 percent for men. Higher female unemployment may be explained, inter alia, by lower education and literacy rates. In situations of declining demand during the liberalized and deflationary period, women were pushed into the informal sector.

Overall, the post-apartheid period and increased globalization have been associated with higher female participation rates in the labor force. However, we notice that the feminization of the labor force is accompanied by an increase in female unemployment. Where employment has grown, this seems to have been mostly in self-employment in the informal sector. Accordingly, given that there has been no appreciable increase in the demand for female labor in the formal sector, these findings may reflect an increasing number of women who are "pushed" into the labor market (Casale \& Posel, 2002).

Data on earnings distribution by gender in the apartheid period are sparse but are generally thought to confirm discrimination along racial lines. Fallon and Lucas (1998) find that, while education and experience are important determinants of earnings, other factors such as discrimination by race and gender and barriers to mobility (i.e. geographic location and formal/informal economic activity) are associated with larger differentials than usually found in studies for other countries. In a recent study, Rospabe (2002) shows that Black Africans earn the lowest incomes, followed by Coloureds and Indians, while Whites have the highest earnings.

According to the 1997 October Household Survey, African workers earned, on average, 63 percent less than White workers. As later surveys have shown, this racial wage gap, though still significant, is smaller in community, social and personal services than in other sectors. The gap has tended to narrow in the long run, though data should be interpreted with caution due to methodological changes (see Hofmeyr, 1993; Crankshaw, 1997). According to ILO (1999), during the last few years the gap seems to have remained unchanged. The continuing increase of the relative wages of African workers in community services may be due to policy changes in the public sector after the end of apartheid.

The same narrowing in the globalized era has not been perceived in the gender wage gaps from available anecdotal evidence. There is a growing literature showing gender differences are also seen in terms of earnings. 

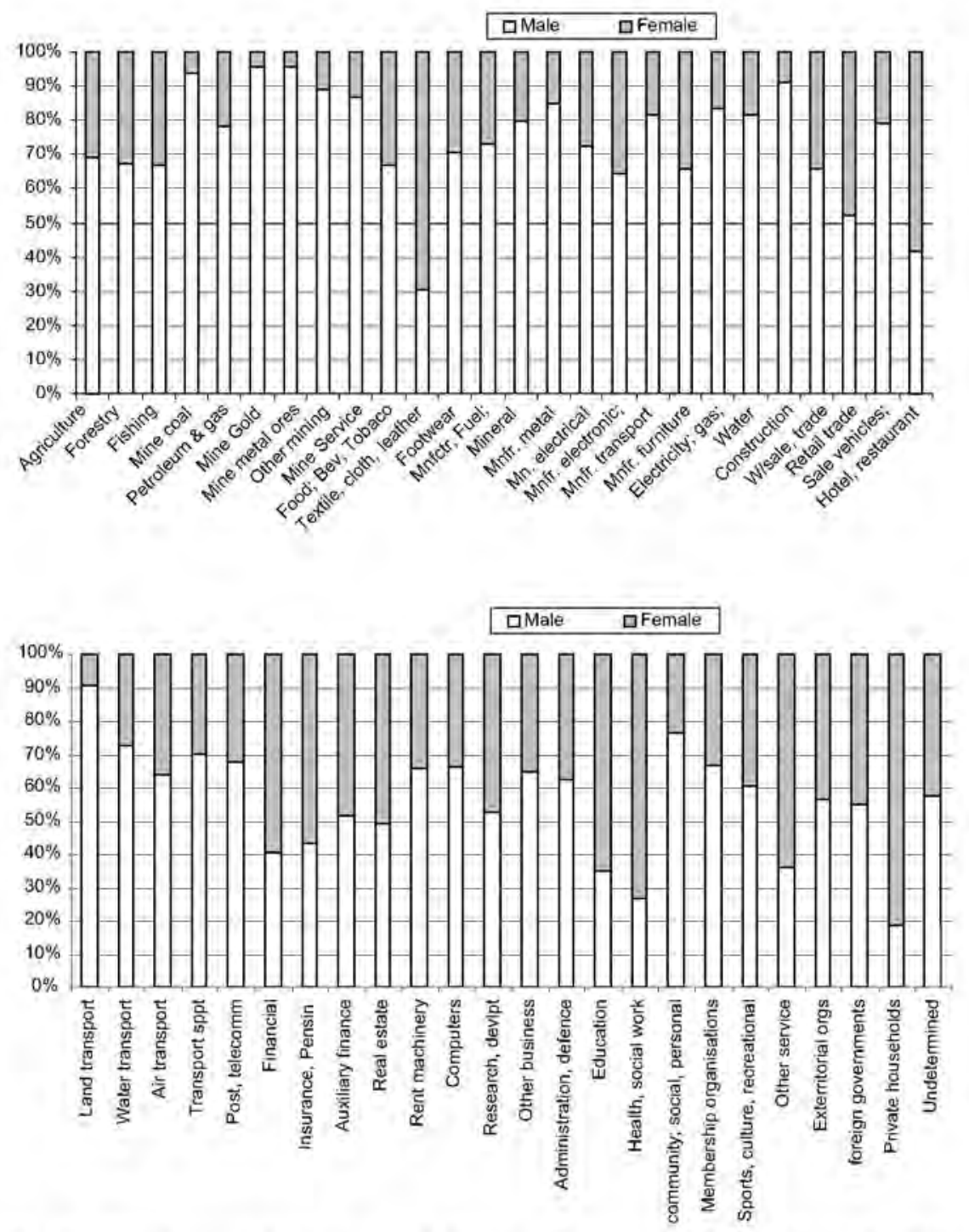

Fig. 2. Employment by Sector and Gender. Source: Calculation from the 2001 Census. 
Table 2. Unemployment (Official Definition) by Race and Gender (2001).

\begin{tabular}{lrc}
\hline Population Group and Area & \multicolumn{2}{c}{ Unemployed Rate (\%) } \\
\cline { 2 - 3 } & Male & Female \\
\hline All population groups & 24.8 & 28.0 \\
Urban & 24.1 & 28.6 \\
Non-urban & 26.4 & 26.9 \\
African & 30.0 & 32.3 \\
Urban & 31.0 & 35.7 \\
Non-urban & 28.6 & 27.9 \\
Colored & 21.1 & 22.8 \\
Urban & 23.9 & 23.7 \\
Non-urban & 8.8 & 17.1 \\
Indian/Asian & 13.9 & 23.0 \\
Urban & 13.5 & 22.9 \\
Non-urban & 31.4 & 30.1 \\
White & 5.6 & 7.8 \\
Urban & 5.7 & 8.0 \\
Non-urban & 4.9 & 5.4 \\
\hline
\end{tabular}

Source: Statistics South Africa (2001a).

According to Fig. 3, there are substantial monthly earning differentials in favor of men.

Women are estimated to earn 65-95 percent less than men in formal sector employment (Valodia, 1996). Using the October household survey for 1999, Rospabe (2002) shows that the cumulative earnings distribution of female workers is first order dominated by the distribution of income for male workers. Further, it was found that women's earnings were more severely affected in manufacturing than in other sectors, with women's earnings equal to 73 percent of men's in metropolitan areas. This is mainly because of the lower positions of women (Pillay, 1993 cited in Budlender, 1995). Budlender (1997) also found that, even for those with the same qualification, there was substantial discrimination in earnings between men and women. Rospabe (2002) estimated the average earnings gap between males and females to be about 20 percent. These differences are attributed to differences in productivity between the two genders and to labor market discrimination against women (Rospabe, 2002). 


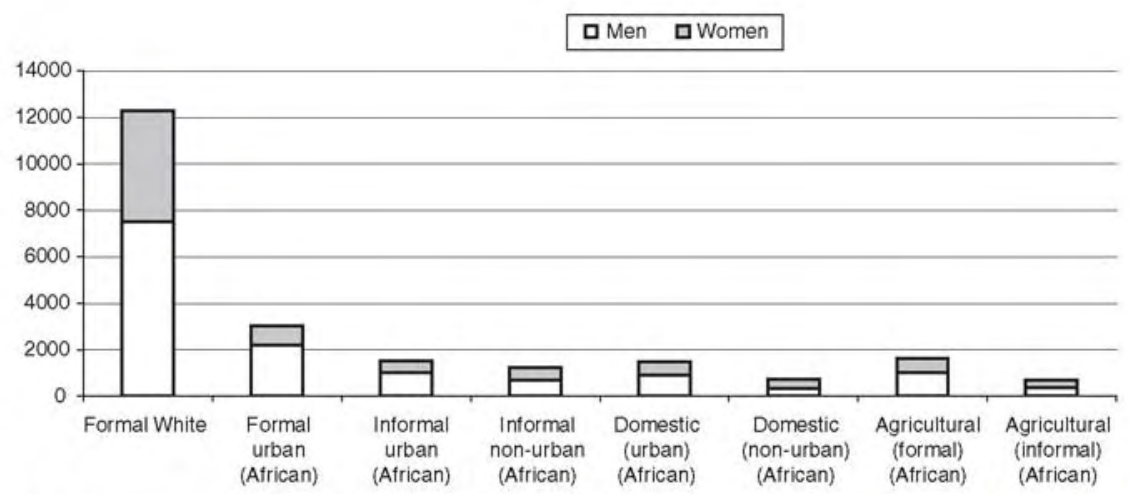

Fig. 3. Mean Monthly Income by Gender (1999). Source: Statistics South Africa (1999).

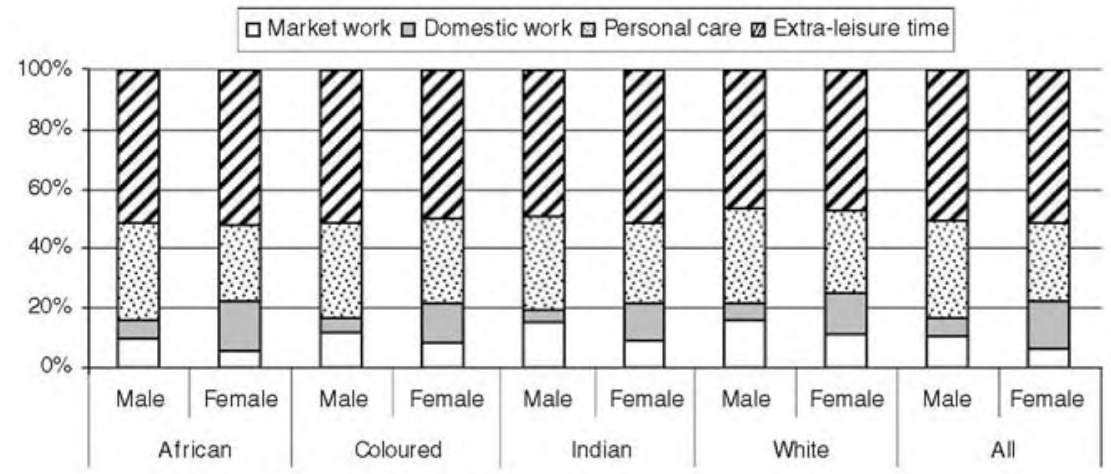

Fig. 4. Household and Gender Time Allocation.

The 2000 South African survey of time use shows that men have more market labor and leisure time. Women do more of the work of rearing and caring for children, caring for other household members, cooking and cleaning (Fig. 4).

\section{BUILDING A GENDER-FOCUSED INTEGRATED MACRO- MICRO MODEL}

Our gender-focused integrated micro-macro model is constructed in three steps. First, we prepare an accounting framework that brings together market and non-market 
activities using macro- and microeconomic datasets for South Africa. Then, we incorporate into a standard CGE model labor market segmentation between male and female workers. These are considered as different factors of production in the same way workers are differentiated according to skill or geographical location in other contexts. Finally, we introduce non-market activities and leisure time into the model with the recognition that women are more likely to perform household work, while men are more active in the labor market and have more leisure time.

\subsection{Building a Gender-Focused Social Accounting Matrix with Household-Level Data}

A CGE model is generally built on the basis of a social accounting matrix (SAM). A gender-focused SAM further distinguishes labor factors by gender. Integrating real households from a representative survey of the population requires vectors of household income and expenditures, as well as data on their market and non-market time allocation. In this process, we use both macro- and microlevel datasets, which we reconcile in a single framework.

Fig. 5 illustrates the procedure used in building a gender-focused SAM with household-level data on income, expenditures and the allocation of time to various activities. We first bring together the Supply and Use Tables (SUT) and the integrated economic accounts (IEA), both for year 2000, in a single framework: a standard SAM (step one). Then, household-level data on income and expenditure as well as male and female market work, are computed from household surveys, i.e. the Income and Expenditure Survey (IES) and the September Labor Force Survey ${ }^{7}$ (LFS), once again both for year 2000 (step two). We then reconcile these household-level data and the standard SAM to generate a gender-disaggregate SAM (step three). Fourth, the time use survey (TUS) for year 2000 is combined with household income and expenditure data, and individual market work data, to impute time spent by individuals in nonmarket activities, i.e. domestic work, leisure and personal care activities (step four). Fifth, household non-market work, leisure and personal care time are incorporated into the gender-disaggregate SAM to generate a gender-focused SAM (step five). The concept of a National Satellite Account of Household Production (NSAHP) is used to incorporate non-market activities (household production of services and leisure activities) into the standard SAM as recommended by the 1993 System of National Accounts of the United Nations. 


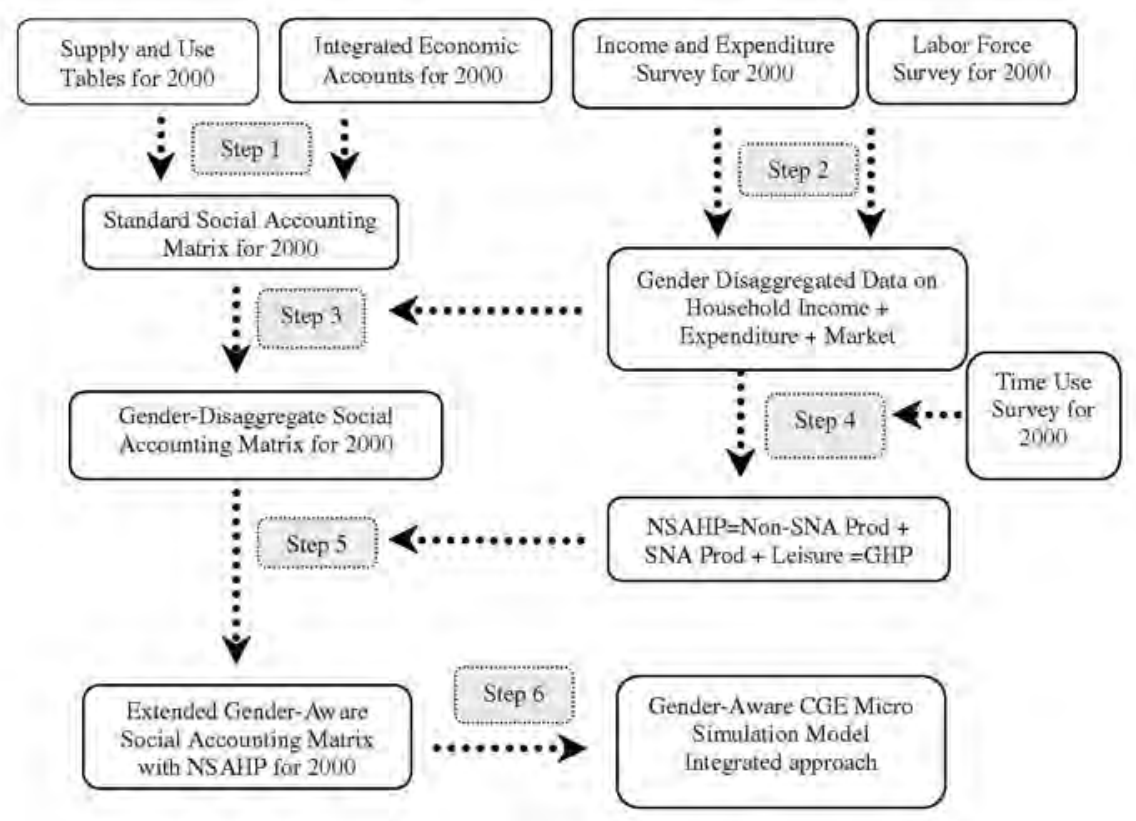

Fig. 5. From NSAHP to a Gender-Focused CGE Microsimulation Model.

The sixth and final stage is to distinguish each individual household within the SAM in order to obtain a gender-focused SAM with real households.

In this procedure, time spent by individuals on non-market work and leisure activities is converted into monetary value by assigning a price. The opportunity cost approach is used to impute a unitary value to the time spent by individuals on various non-market activities. This price is approximated to the "expected" wage rate that an individual would have received if he or she had sold his/her time (or labor services) to the market rather than performing non-market activities. The expected wage rate is predicted for each individual in the household based on individual characteristics (age, gender, etc.).

The estimated value of non-market labor is used as an indicator of the value of household production. Therefore, home-produced goods "directly" require neither capital nor inputs by assumption. Substitution and complementarity between durable and non-durable goods in the home production of services are "indirectly" integrated in the consumption decisions of households. 


\subsection{The Gender-Focused Integrated Macro-Micro Model}

This study uses a CGE model based on the neoclassical-structuralist specification presented in Decaluwe, Martens, and Savard (2001). The model seeks to explain production, consumption and prices in an economy in which consumers and producers respond to relative prices based on welfare and profit maximizing consumption and production behavior, and markets simultaneously adjust relative prices in order to clear markets. Though, most of the equations have strong microeconomic foundations, the conceptualization of the economy also allows a strict macroeconomic analysis such that the behavior of agents is consistent with macroeconomic constraints.

The model incorporates additional features of particular interest for developing countries. The model explicitly treats trade and transportation margins for commodities that enter the market sphere. A constant trade and transportation margins coefficient is added to each transaction, included in the price, and the corresponding revenues generated are a source of demand for the trade and transportation sector.

Labor markets have been treated to reflect empirical evidence in developing countries and South African specificities. Initially, there are eight categories of workers distinguished by their residential area (urban and rural), age (child and adult) and skill categories in the case of adult workers (high, medium and low). The model explicitly treats unemployment as a consequence of labor market imperfections in South Africa.

Most standard CGE models make the implicit assumption that male and female workers are perfect substitutes in market production and thus do not distinguish them. However, many studies underline the fact that there is segmentation in the labor market between men and women, and different levels of market work flexibility according to the domestic tasks they perform. Also, it is observed that male and female workers tend to concentrate in different sectors and occupations, which further undermines the hypothesis of perfect substitutability. Finally, it is widely recognized that there is often a gender bias against women in the labor market in term of wage earnings and job opportunities. Indeed, the 2002 report on men and women in South African shows that the unemployment rate is higher for women than for men within each population group, and in both urban and rural areas. Formal sector work is far more common for men than for women. Employed women tend to cluster into a small number of industries compared to men; and women are significantly more likely than men to be employed in clerical jobs while men are primarily employed as operators. 
Mean hourly earnings are higher for men than women across all population groups. Therefore, the first step of the modeling exercise will consist in the segmentation of the labor market into male and female workers to highlight the gender bias observed in the South African economy.

Therefore, male labor $\left(\mathrm{LD}_{i}^{\mathrm{mal}}\right)$ and female labor are $\left(\mathrm{LD}_{i}^{\mathrm{fem}}\right)$ imperfect substitutes in the aggregate sector $i$ labor demand $\left(\mathrm{LD}_{i}\right)$. The conditional demand of male and female labor depends on initial sectoral shares, wage rates and their degree of substitution in sectoral production.

$$
\mathrm{LD}_{i}=f\left(\mathrm{LD}_{i}^{\mathrm{mal}}, \mathrm{LD}_{i}^{\mathrm{fem}}\right)
$$

The gross earnings of male and female workers are equal to the volume of labor services demanded by productive sectors valued at market wage rates. Household labor income $\left(Y_{h}\right)$ consists of male and female wage incomes.

Assuming labor market imperfections and the presence of unemployment, only a proportion of the total hours supplied by households to the labor market is hired. $\mathrm{LS}_{h}$ is household $h$ labor supply, $w$ and $u$ the rate of wage and the rate of unemployment, respectively.

$$
Y_{h}=f\left(\mathrm{LS}_{h}^{\mathrm{mal}}, \mathrm{LS}_{h}^{\mathrm{fem}}, w^{\mathrm{mal}}, w^{\mathrm{fem}}, u^{\mathrm{mal}}, u^{\mathrm{fem}}\right)
$$

We introduce non-market activities into the model with the recognition that women are more likely to perform household work while men are more active in the labor market and have more leisure time. Furthermore, modeling non-market activities alongside market activities makes it possible to assess (i) the importance of household production of services which are intensive in female work. These services, which are not sold in the market and therefore entirely consumed by the household, enter in competition with their market substitutes, ${ }^{8}$ (ii) the impact of constraints faced by women at the household level (because of their involvement in family tasks) that may negatively affect their labor market participation and the performance of the overall economy, (iii) the impacts on female leisure time. Increased female participation in the labor force will not necessarily improve their welfare if they still perform most of the domestic work and must therefore reduce their leisure time, and (iv) the impact on child education at the household level. If children, especially girls, are required to assume the household tasks of female adults who have entered the labor market, their education and leisure time could be negatively affected.

Men and women substitute the time devoted to leisure and to the production of home goods, which are imperfect substitutes for market goods. ${ }^{9}$ Male $\left(\mathrm{LZ}_{h}^{\mathrm{mal}}\right)$ and female domestic work $\left(\mathrm{LZ}_{h}^{\mathrm{fem}}\right)$ are imperfect substitutes in home good production $\left(Z_{h}\right)$, which, by assumption, does not require either 
intermediate goods or capital. ${ }^{10}$

$$
Z_{h}=f\left(\mathrm{LZ}_{h}^{\mathrm{mal}}, \mathrm{LZ}_{h}^{\mathrm{fem}}\right)
$$

The relative demand for male and female labor in home production depends on their relative share $\left(\alpha_{h}^{\mathrm{mal}}\right.$ and $\left.\alpha_{h}^{\mathrm{fem}}\right)$ in home production, male and female expected wage rates ( $w^{\text {mal }}$ and $\left.w^{\text {fem }}\right)$ and the degree of trade-off between men and women in home production represented by the elasticity of substitution ${ }^{11}\left(\varepsilon_{h}\right)$.

$$
\frac{\mathrm{L} Z_{h}^{\mathrm{mal}}}{\mathrm{L} Z_{h}^{\mathrm{fem}}}=f\left(\alpha_{h}^{\mathrm{mal}}, \alpha_{h}^{\mathrm{fem}}, w^{\mathrm{mal}}, w^{\mathrm{fem}}, \varepsilon_{h}\right)
$$

The value of home-produced goods is equal to the value of the labor devoted to their production, where non-market labor is valued at its opportunity cost as measured by the expected market wage rates.

An extended linear expenditure system is specified to derive household demand for home goods subject to full income; where $\ell_{h}^{\mathrm{mal}}$ and $\ell_{h}^{\mathrm{fem}}$ represent male and female leisure time, respectively; $C_{h}^{z}$ and $C_{h i}^{m}$ are home produced goods and market goods consumptions, respectively.

$$
U_{h}=f\left(C_{h, i}^{m}, C_{h}^{z}, \ell_{h}^{\mathrm{mal}}, \ell_{h}^{\mathrm{fem}}\right)
$$

Men and women allocate their total available time in two steps. First, the total exogenous time (hours) available for market and non-market activities are allocated to domestic activities (according to home goods production requirement and the degree of substitutability among men and women in home production), to leisure activities (the demand for male and female leisure is derived from the utility function) and to market activities as residuals. Second, the hours of labor supplied to the market is allocated between work and unemployment. ${ }^{12}$

\section{SIMULATIONS AND RESULTS}

Our first simulation involves the elimination of all import tariffs where government revenue is held constant through the introduction of an endogenous adjustment in indirect taxes. Trade liberalization emerges as one of the key policy issues of the GEAR agenda discussed in previous sections. Although other trade barriers still exist, tariffs constitute the principal protectionist 
measure in South Africa. The removal of tariffs in South Africa modifies the entire price structure and, consequently, factor returns. The impact on households depends on their factor endowments and their consumption patterns. Trade liberalization also has differential impacts on men and women depending on the sectors in which they are intensively employed and the household to which they belong.

\subsection{Trade and Output Effects}

The initial impact of the removal of all tariffs is a fall in the domestic price of imports that is particularly strong in the highly protected sectors. Local consumers react to the fall in import prices by increasing their imports by sector roughly in the same proportion as the fall in sectoral tariff rates. Given a fixed current account balance, the increase in imports leads to a 4.9 percent exchange rate depreciation, which partially offsets the fall in import prices in these sectors and leads to an increase in the domestic price of imports in some other sectors (see Appendix 1). Of course, this import surge comes at the expense of domestic competitors, who experience a decline in the volume and price of their sales on the local market. Given the imperfect substitution between local and imported goods (CES), as well as the relatively small initial import intensities (imports/domestic consumption), the changes here are proportionally much smaller than the variations in import volumes. Nonetheless, the sectors with the most substantial reductions in local sales are the highly protected sectors.

The exchange rate depreciation also results in a 1.8 percent increase in export volume. Exports increase most in the export-intensive sectors, i.e. the sectors with the highest initial export intensity ratios (Exports/Output). These sectors are identified in italics in Appendix 1. Variations in exports and domestic sales determine changes in total output. Given their loss in domestic sales, the highly protected sectors also experience the strongest output declines.

Output prices are averages of export prices, which are assumed fixed, and domestic prices, weighted by the share of sales on each of these markets. Thus, it is unsurprising that they fall strongly in most of the highly protected sectors, while they increase in sectors with initially low tariff rates. Note that these are after-tax output price variations and thus include a 13.4 percent increase in the indirect tax rate required to balance the government's budget, whereas the import and domestic sales price variations are shown net of indirect taxes. 


\subsection{Factor Effects}

We now examine how the trade and output effects above influence factor prices and unemployment rates, crucial components of the ultimate welfare and poverty effects.

To understand these results, note that factor prices are driven by value-added prices as the source of their remuneration. While changes in value-added prices generally reflect output price variations, their evolution is more positive (less negative) when input costs rise less (fall more) than output prices. Thus valueadded prices generally fall most among the highly protected sectors whereas they increase among sectors with low initial tariffs. However, export-oriented industries are among the sectors with the strongest increases in value-added prices. Indeed, beyond the modest increase in their output prices, these sectors benefit more from falling input costs, given the high share of their inputs that come from the initially highly protected sectors. The contrary is true for the high value-added (low input) agricultural sector, in which value-added prices fall. The rest of this table shows the shares of total income that each factor derives from each of the sectors (Appendix 2).

The relationship between the wage rate and the unemployment rate is represented by a downward-sloping relation (the "wage curve"). As a result, rising (falling) wage rates are associated with falling (rising) unemployment rates. Essentially, rising demand for certain types of labor translates into increased wages and employment, whereas falling demand has the opposite effect. Consequently, we focus our analysis here on the wage impacts with the understanding that the unemployment effects are generally the mirror image.

To explain wage impacts, we refer throughout to the value-added price variations and factor intensities in Appendix 2. Whereas public sector employment and wage rates are assumed fixed, private sector workers are assumed to be mobile between sectors with wage rates that equalize across all private sectors. We note substantial differences in private sector wage and unemployment rate changes according to the gender, skills and location of workers (Table 3).

Male wage rates generally evolve more favorably than female wage rates, with the exception of high-skilled urban and low-skilled rural workers. Female workers are penalized by their greater participation in garments, as well as health and social work, for which value-added prices fall (Appendix 2). In contrast, male workers benefit from their strong participation in mining activities, which offsets their dependency on agricultural wages, especially in rural areas. Among child workers, in both rural and urban South Africa, the decline in wage rates for girls can be traced primarily to their greater 
Table 3. Wage and Unemployment Rate Variations

\begin{tabular}{|c|c|c|c|c|c|c|c|c|c|c|c|}
\hline & \multicolumn{4}{|c|}{ Urban } & \multirow[t]{2}{*}{ Urban All } & \multicolumn{4}{|c|}{ Rural } & \multirow[t]{2}{*}{ Rural All } & \multirow[t]{2}{*}{ All } \\
\hline & High skill & Medium skill & Low skill & Child & & High skill & Medium skill & Low skill & Child & & \\
\hline \multicolumn{12}{|c|}{ Change in wage rates } \\
\hline Males & -0.01 & 0.05 & 0.02 & -0.09 & 0.02 & -0.01 & 0.02 & -0.12 & -0.24 & -0.01 & 0.02 \\
\hline Females & 0.01 & 0.01 & -0.01 & -0.09 & 0.01 & -0.04 & -0.06 & -0.09 & -0.64 & -0.06 & 0.00 \\
\hline All & -0.01 & 0.04 & 0.01 & -0.09 & 0.02 & -0.02 & 0.00 & -0.11 & -0.31 & -0.03 & 0.01 \\
\hline \multicolumn{12}{|c|}{ Change in unemployment rates } \\
\hline Males & 0.14 & -0.53 & -0.24 & 0.83 & -0.31 & 0.13 & -0.09 & 1.17 & 1.85 & 0.09 & -0.27 \\
\hline Females & -0.10 & -0.10 & 0.07 & 0.37 & -0.08 & 0.40 & 0.58 & 0.88 & 6.59 & 0.56 & -0.03 \\
\hline All & 0.05 & -0.38 & -0.10 & 0.52 & -0.23 & 0.25 & 0.04 & 1.05 & 2.77 & 0.23 & -0.18 \\
\hline
\end{tabular}


participation in agriculture, whereas boys diversify into a number of services sectors where prices generally rise modestly.

Capital is assumed to be sector-specific because of the short-term horizon of our analysis. As a result, variations in the rates of returns to capital closely follow changes in the value-added prices of their respective sectors. These rates fall most in the highly protected sectors and increase in the expanding exportoriented sectors (Appendix 2).

\subsection{Time Allocation Analysis}

We have already noted that men are more active in the labor market than women, whereas women are more heavily involved in domestic work. We also noted that men and women tend to work in different sectors. Most sectors are male intensive with the notable exceptions of textiles and garments and a number of service sectors.

Households respond to the changes in real wage rates for male and female workers by changing their allocation of time between market and non-market activities. Labor market participation decisions depend on labor and non-labor income effects, which are taken at the household level. As a consequence, higher real wage rates will not necessarily induce an increase in the labor market participation of workers as labor income from other members, non-labor income and non-market activities may also play important roles.

Women, especially in urban areas, increase their market participation while male market participation stagnates (Table 4). Male and female market participation in rural areas fall as their real wage rates decrease. Female market participation increases within the Black population category, because of their low endowment of high- and medium-skilled workers that win from tariff elimination in South Africa, and decrease within other household categories.

Men and women work more at home, as they substitute market goods with rising prices by home produced goods. Although females already do more domestic work than men, they continue to carry out most of the domestic tasks, especially in urban areas. Their market and non-market work increase is roughly double that of men, at the expense of their pure leisure time. As a large proportion of their time spent outside market work is devoted to leisure activities rather than domestic work, men perform even less domestic work with trade liberalization, especially in urban areas and within female-headed household categories. 
Table 4. Change in Hours Worked (Percent Variation).

\begin{tabular}{|c|c|c|c|c|c|c|c|c|c|c|c|c|c|c|c|c|c|c|c|c|c|c|}
\hline & \multicolumn{11}{|c|}{ Market Work } & \multicolumn{11}{|c|}{ Domestic Work } \\
\hline & $\begin{array}{l}\text { Urban } \\
\text { high } \\
\text { skill }\end{array}$ & $\begin{array}{l}\text { Urban } \\
\text { medium } \\
\text { skill }\end{array}$ & $\begin{array}{l}\text { Urban } \\
\text { low } \\
\text { skill }\end{array}$ & $\begin{array}{l}\text { Urban } \\
\text { child }\end{array}$ & $\begin{array}{c}\text { All } \\
\text { urban }\end{array}$ & $\begin{array}{c}\text { Rural } \\
\text { high } \\
\text { skill }\end{array}$ & $\begin{array}{l}\text { Rural } \\
\text { medium } \\
\text { skill }\end{array}$ & $\begin{array}{l}\text { Rural } \\
\text { low } \\
\text { skill }\end{array}$ & $\begin{array}{l}\text { Rural } \\
\text { child }\end{array}$ & $\begin{array}{l}\text { All } \\
\text { rural }\end{array}$ & All & $\begin{array}{l}\text { Urban } \\
\text { high } \\
\text { skill }\end{array}$ & $\begin{array}{l}\text { Urban } \\
\text { medium } \\
\text { skill }\end{array}$ & $\begin{array}{l}\text { Urban } \\
\text { low } \\
\text { skill }\end{array}$ & $\begin{array}{l}\text { Urban } \\
\text { child }\end{array}$ & $\begin{array}{c}\text { All } \\
\text { urban }\end{array}$ & $\begin{array}{l}\text { Rural } \\
\text { high } \\
\text { skill }\end{array}$ & $\begin{array}{l}\text { Rural } \\
\text { medium } \\
\text { skill }\end{array}$ & $\begin{array}{l}\text { Rural } \\
\text { low } \\
\text { skill }\end{array}$ & $\begin{array}{l}\text { Rural } \\
\text { child }\end{array}$ & $\begin{array}{c}\text { All } \\
\text { rural }\end{array}$ & ${ }_{1}^{\text {All }}$ \\
\hline \multicolumn{23}{|l|}{ South Africa } \\
\hline Male & -0.01 & -0.01 & 0.01 & 0.01 & 0.00 & 0.00 & -0.04 & -0.04 & -0.55 & -0.02 & 0.00 & -0.01 & 0.01 & -0.09 & -0.03 & -0.04 & 0.03 & 0.01 & 0.89 & 0.87 & 0.56 & 0.07 \\
\hline Female & 0.00 & -0.02 & 0.07 & 0.03 & 0.04 & -0.03 & -0.04 & -0.54 & 0.00 & -0.03 & 0.03 & 0.08 & 0.00 & -0.01 & 0.05 & 0.03 & 0.23 & -0.05 & 0.47 & 1.11 & 0.54 & 0.14 \\
\hline \multirow{2}{*}{\multicolumn{23}{|c|}{$\begin{array}{l}\text { Head of household } \\
\text { Male head }\end{array}$}} \\
\hline & & & & & & & & & & & & & & & & & & & & & & \\
\hline Male & -0.01 & -0.01 & 0.01 & -0.01 & 0.00 & -0.01 & -0.06 & -8.04 & 0.00 & -0.02 & 0.00 & -0.01 & 0.01 & -0.06 & 0.00 & -0.02 & 0.04 & 0.03 & 1.02 & 0.90 & 0.61 & 0.09 \\
\hline Female & 0.00 & -0.01 & 0.07 & -0.16 & 0.04 & -0.02 & -0.02 & -0.07 & 0.00 & -0.02 & 0.03 & 0.08 & -0.02 & -0.05 & -0.01 & -0.02 & 0.21 & -0.10 & 0.52 & 1.01 & 0.47 & 0.08 \\
\hline \multicolumn{23}{|c|}{ Female head } \\
\hline Male & -0.01 & 0.00 & 0.09 & 0.04 & 0.03 & 0.04 & -0.03 & 0.00 & -2.85 & -0.03 & 0.02 & 0.04 & 0.01 & -0.17 & -0.08 & -0.10 & -0.06 & 0.00 & 0.69 & 0.83 & 0.47 & 0.04 \\
\hline Female & -0.01 & -0.02 & 0.04 & 0.09 & 0.04 & -0.11 & -0.05 & -4.66 & 0.00 & -0.07 & 0.02 & 0.09 & 0.01 & 0.05 & 0.10 & 0.08 & 0.30 & -0.02 & 0.42 & 1.19 & 0.60 & 0.20 \\
\hline \multicolumn{23}{|c|}{ Population group } \\
\hline \multicolumn{23}{|l|}{ Black } \\
\hline Male & -0.01 & 0.00 & 0.00 & 0.01 & 0.00 & 0.00 & -0.04 & -0.04 & 0.00 & -0.02 & 0.00 & 0.03 & -0.02 & -0.10 & -0.04 & -0.05 & 0.04 & 0.01 & 0.90 & 0.86 & 0.53 & 0.08 \\
\hline Female & 0.00 & -0.01 & 0.09 & 0.03 & 0.06 & -0.03 & -0.04 & -0.79 & 0.00 & -0.03 & 0.04 & 0.06 & -0.02 & -0.01 & 0.05 & 0.03 & 0.25 & -0.05 & 0.47 & 1.11 & 0.55 & 0.14 \\
\hline \multicolumn{23}{|l|}{ Colored } \\
\hline Male & -0.01 & 0.00 & 0.02 & -0.02 & 0.00 & 0.00 & -0.04 & 0.00 & -5.76 & -0.04 & 0.00 & 0.04 & -0.02 & -0.08 & -0.02 & -0.04 & -0.01 & 0.01 & 0.91 & 0.87 & 0.57 & 0.10 \\
\hline Female & 0.00 & 0.00 & 0.04 & -0.13 & 0.02 & -0.08 & -0.01 & -0.14 & 0.00 & -0.06 & -0.02 & 0.00 & -0.11 & 0.03 & 0.06 & 0.05 & 0.15 & -0.04 & 0.35 & 1.01 & 0.26 & 0.13 \\
\hline \multicolumn{23}{|l|}{ Asian } \\
\hline Male & 0.00 & -0.02 & 0.01 & -0.01 & 0.00 & 0.02 & 0.00 & 0.00 & 0.00 & 0.00 & 0.00 & 0.08 & 0.02 & -0.07 & -0.03 & -0.03 & 0.00 & -0.05 & 1.03 & 0.84 & 0.68 & 0.09 \\
\hline Female & 0.00 & 0.00 & 0.00 & 0.00 & 0.00 & -0.02 & 0.00 & 0.00 & 0.00 & -0.02 & -0.02 & 0.00 & 0.00 & 0.00 & -0.02 & -0.02 & 0.10 & 0.00 & 0.00 & 1.15 & 0.54 & 0.07 \\
\hline \multicolumn{23}{|l|}{ White } \\
\hline Male & 0.00 & -0.01 & 0.02 & 0.02 & 0.00 & 0.00 & -0.08 & 0.00 & 0.00 & -0.02 & 0.00 & -0.03 & 0.01 & -0.09 & -0.02 & -0.03 & 0.04 & 0.11 & 0.86 & 0.94 & 0.68 & 0.04 \\
\hline Female & 0.00 & -0.13 & 0.00 & 0.01 & 0.00 & 0.03 & 0.03 & 0.00 & 0.00 & 0.03 & 0.00 & 0.11 & 0.10 & 0.05 & 0.04 & 0.05 & 0.23 & -0.24 & 0.45 & 1.20 & 0.73 & 0.10 \\
\hline \multicolumn{23}{|l|}{ Unspecined } \\
\hline Male & -0.04 & -0.62 & -0.44 & 0.00 & -0.13 & 0.03 & -0.10 & 0.00 & 0.00 & -0.02 & -0.13 & 0.04 & 0.44 & -0.06 & -0.04 & -0.01 & 0.02 & -0.01 & 0.51 & 0.87 & 0.42 & 0.04 \\
\hline Female & 0.00 & 0.00 & 0.00 & 0.00 & 0.00 & 0.00 & 0.00 & 0.00 & 0.00 & 0.00 & 0.00 & 0.00 & 0.00 & 0.00 & 0.00 & 0.00 & 0.00 & 0.00 & 0.00 & 0.00 & 0.00 & 0.00 \\
\hline
\end{tabular}




\subsection{Income, Consumption and Welfare Effects}

With the CGE microsimulation approach, we obtain income variations for each individual household, which we can then group in a variety of ways. We present results grouped according to residential area, population group and the gender of the household head. We first note that wages are the principal source of income in South Africa, followed by various forms of transfers (from other households, government, etc.), although there are substantial differences between household groups.

Overall, incomes do not change significantly (see Table 5). Incomes evolve more favorably in urban than rural areas, as a consequence of rising wage rates and market participation, and the capital remuneration effects. Male-headed households benefit from trade reform policy, whereas female-headed households suffer from a significant drop in the returns to their capital. All population groups except "White", which shows a stagnation in income, benefit from free trade in terms of income. The "Asian" population group is the big winner, as they benefit from a significant increase of the returns to their capital.

In addition to its income effects, trade liberalization influences household welfare by changing consumer prices. While pre-tax prices fall both for imports and, in the face of increased import competition, domestic goods, consumer prices increase by 0.9 percent due to exchange rate depreciation and the increase in the sales tax required to offset lost tariff revenues. The required increase in the initial indirect tax rate (surtax) is quite small (13.4 percent) due to the relative small share of tariffs in government revenue and the average sale tax of 4.5 percent. However, consumption prices for agriculture goods increase less than services and manufacturing goods, as they present the smallest average tax rate.

Each household is affected differently by consumer price reductions according to its consumption patterns. In this respect, we note that consumer prices increase for all household, consequently, tariff elimination on imports leads to a welfare loss in South Africa.

\subsection{Poverty and Inequality Analysis}

The advantage of the integrated CGE microsimulation approach is its capacity to capture the heterogeneity of household income sources and consumption patterns in order to perform the between- and within-group distribution, poverty and inequality analysis. The model is used to generate the post-simulation data. 
Table 5. Household Income and Expenditure Effects (in Percent).

\begin{tabular}{|c|c|c|c|c|c|c|c|c|c|c|}
\hline & \multirow[t]{2}{*}{ South Africa } & \multicolumn{2}{|c|}{ Residential Area } & \multicolumn{2}{|c|}{ Head of Household } & \multicolumn{5}{|c|}{ Population Group } \\
\hline & & Urban & Rural & Male head & Female head & Black & Colored & Asian & White & Unspecified \\
\hline All incomes & 0.04 & 0.09 & -0.27 & 0.06 & -0.04 & 0.04 & 0.05 & 0.16 & 0.00 & 0.46 \\
\hline Income taxes & -0.21 & -0.21 & -0.16 & -0.23 & 0.00 & 0.04 & 0.08 & 0.05 & -0.29 & 0.12 \\
\hline Transfers out & 0.00 & 0.00 & 0.00 & 0.00 & 0.00 & 0.00 & 0.00 & 0.00 & 0.00 & 0.00 \\
\hline Savings & 0.22 & 0.44 & -1.22 & 0.40 & -0.10 & 0.07 & 0.02 & 0.23 & 2.67 & 1.68 \\
\hline Consumption & 0.05 & 0.09 & -0.13 & 0.07 & -0.02 & 0.04 & 0.07 & 0.12 & 0.05 & 0.05 \\
\hline Consumer price index & 0.92 & 0.89 & 1.05 & 0.90 & 0.99 & 0.86 & 0.79 & 1.19 & 0.99 & 0.72 \\
\hline $\mathrm{EV} /$ initial income & -0.23 & -0.21 & -0.35 & -0.24 & -0.15 & -0.17 & -0.11 & -0.17 & -0.31 & -0.33 \\
\hline
\end{tabular}


Then these data and the base year data drawn from the income and expenditure survey are used to compute and compare standard consumption-based poverty and inequality indicators.

Foster-Greene-Thorbecke (FGT) poverty indicators (i.e. headcount index, poverty gap and squared poverty gap) and the Theil inequality index are adopted. We define the poverty line as 3,864 South African rands per year in 2000 prices, a lower bound poverty line suggested by Hoogeveen and Ozler (2004). Post-liberalization consumption data are deflated by the Laspeyres economy-wide consumer price index to account for the change in the general price level.

Results presented in Table 6 suggest that the impacts of complete tariff removal on poverty are small. Poverty and inequality increase slightly. Poverty indicators increase more in rural areas than in urban areas. This is confirmed by the increasing inequality in rural areas. Poverty increase more among femaleheaded, colored and Black households, whereas they increase slightly or remain stable for male-headed, Asian, White and unspecified households.

Our analysis until now has been at the household level. However, given our preoccupation with the gender impacts of trade liberalization, we exploit the microsimulation aspect of our analysis, including detailed information on all individuals in the sample households, to analyze poverty and inequality impacts

Table 6. Poverty and Inequality Indexes (in Percent).

\begin{tabular}{|c|c|c|c|c|c|c|c|c|}
\hline & \multicolumn{4}{|c|}{ Initial Values } & \multicolumn{4}{|c|}{ Variation } \\
\hline & $\mathrm{P} 0$ & $\mathrm{P} 1$ & $\mathrm{P} 2$ & Theil index & $\mathrm{P} 0$ & $\mathrm{P} 1$ & $\mathrm{P} 2$ & Theil index \\
\hline South Africa & 53.0 & 25.3 & 15.0 & 1.6 & 0.29 & 0.26 & 0.20 & 0.06 \\
\hline \multicolumn{9}{|l|}{ Residential area } \\
\hline Urban & 42.4 & 18.4 & 10.2 & 1.6 & 0.23 & 0.21 & 0.14 & -0.01 \\
\hline Rural & 68.3 & 35.4 & 22.1 & 1.0 & 0.37 & 0.34 & 0.27 & 0.07 \\
\hline \multicolumn{9}{|l|}{ Head of household } \\
\hline Male & 43.6 & 19.5 & 11.1 & 1.6 & 0.19 & 0.22 & 0.15 & 0.03 \\
\hline Female & 65.8 & 33.4 & 20.5 & 0.8 & 0.43 & 0.32 & 0.26 & 0.03 \\
\hline \multicolumn{9}{|l|}{ Population group } \\
\hline Black household & 61.0 & 29.5 & 17.6 & 1.1 & 0.31 & 0.30 & 0.23 & 0.07 \\
\hline Colored household & 36.2 & 14.7 & 7.8 & 0.8 & 0.45 & 0.19 & 0.12 & 0.01 \\
\hline Asian household & 6.4 & 2.3 & 0.8 & 0.3 & 0.00 & 0.04 & 0.03 & 0.01 \\
\hline White household & 0.1 & 0.0 & 0.0 & 1.0 & 0.00 & 0.00 & 0.00 & 0.06 \\
\hline Unspecified household & 11.4 & 3.1 & 0.8 & 1.7 & 0.00 & 0.08 & 0.04 & -0.06 \\
\hline
\end{tabular}

Notes: $\mathrm{P} 0=$ poverty headcount; $\mathrm{P} 1=$ poverty gap; $\mathrm{P} 2=$ poverty severity. 
separately for men, women and children. Note that we do not attempt to integrate issues of intra-household allocation and simply assume that income and consumption are shared evenly. Thus, men, women and children are considered to be poor if they belong to a poor household, i.e. a household for which consumption expenditure per capita is less than the poverty line. It can be shown that these results are robust for a wide range of poverty lines.

Table 7 indicates that, in South Africa, 63 percent of children and 51 percent of women are poor (live in poor households), as compared to only 44 percent of men. This hierarchy is reproduced for all household categories, with the exception of female-headed households, in which the incidence of poverty is

Table 7. Poverty Indexes by Gender and Age.

\begin{tabular}{|c|c|c|c|c|c|c|c|c|c|}
\hline & \multicolumn{3}{|c|}{ Men } & \multicolumn{3}{|c|}{ Women } & \multicolumn{3}{|c|}{ Children } \\
\hline & $\mathrm{P} 0$ & P1 & $\mathrm{P} 2$ & $\mathrm{P} 0$ & P1 & $\mathrm{P} 2$ & $\mathrm{P} 0$ & P1 & P2 \\
\hline \multicolumn{10}{|c|}{ Base year values $(\%)$} \\
\hline South Africa & 43.8 & 19.9 & 11.5 & 50.8 & 23.9 & 14.0 & 62.7 & 31.2 & 19.0 \\
\hline Urban area & 35.1 & 14.9 & 8.1 & 41.6 & 18.1 & 10.0 & 51.7 & 22.8 & 12.8 \\
\hline Rural area & 61.5 & 30.2 & 18.5 & 65.9 & 33.4 & 20.5 & 73.7 & 39.7 & 25.4 \\
\hline Male headed & 36.6 & 15.6 & 8.7 & 41.9 & 18.7 & 10.6 & 53.6 & 24.9 & 14.6 \\
\hline Female headed & 66.0 & 33.2 & 20.3 & 59.4 & 28.9 & 17.3 & 72.6 & 38.1 & 23.9 \\
\hline Black & 51.8 & 23.8 & 13.9 & 60.1 & 28.5 & 16.8 & 68.9 & 34.7 & 21.3 \\
\hline Colored & 30.8 & 11.9 & 6.1 & 34.6 & 14.3 & 7.7 & 43.0 & 17.6 & 9.3 \\
\hline Asian & 5.5 & 2.0 & 0.8 & 2.9 & 1.0 & 0.3 & 12.3 & 4.3 & 1.6 \\
\hline White & 0.0 & 0.0 & 0.0 & 0.2 & 0.1 & 0.1 & 0.0 & 0.0 & 0.0 \\
\hline Unspecified & 0.0 & 0.0 & 0.0 & 7.9 & 2.1 & 0.6 & 21.8 & 5.8 & 1.6 \\
\hline \multicolumn{10}{|c|}{ Variations after simulation (\%) } \\
\hline South Africa & 0.22 & 0.22 & 0.16 & 0.31 & 0.26 & 0.19 & 0.32 & 0.30 & 0.23 \\
\hline Urban area & 0.26 & 0.17 & 0.11 & 0.26 & 0.21 & 0.15 & 0.15 & 0.25 & 0.17 \\
\hline Rural area & 0.13 & 0.32 & 0.24 & 0.39 & 0.34 & 0.27 & 0.50 & 0.35 & 0.29 \\
\hline Male headed & 0.19 & 0.19 & 0.13 & 0.23 & 0.21 & 0.15 & 0.14 & 0.26 & 0.19 \\
\hline Female headed & 0.30 & 0.31 & 0.25 & 0.38 & 0.31 & 0.23 & 0.53 & 0.35 & 0.28 \\
\hline Black & 0.23 & 0.26 & 0.19 & 0.35 & 0.31 & 0.23 & 0.33 & 0.33 & 0.26 \\
\hline Colored & 0.42 & 0.17 & 0.10 & 0.37 & 0.18 & 0.12 & 0.55 & 0.22 & 0.15 \\
\hline Asian & 0.00 & 0.03 & 0.02 & 0.00 & 0.02 & 0.01 & 0.00 & 0.07 & 0.05 \\
\hline White & 0.00 & 0.00 & 0.00 & 0.00 & 0.00 & 0.00 & 0.00 & 0.00 & 0.00 \\
\hline Unspecified & 0.00 & 0.00 & 0.00 & 0.00 & 0.05 & 0.03 & 0.00 & 0.15 & 0.08 \\
\hline
\end{tabular}

Notes: $\mathrm{P} 0=$ headcount index; $\mathrm{P} 1=$ poverty gap; $\mathrm{P} 2=$ squared poverty gap (poverty severity index). 
less among women than among men. Note that this does not reflect intrahousehold allocation, as this is ignored. Instead, it indicates that there tends to be a higher ratio of men to women in poor female-headed households than in non-poor female-headed households. The results of our trade liberalization scenario in the bottom half of Table 7 indicate that poverty increases slightly more among women and children than among their male counterparts. In particular, the elimination of import tariffs is likely to increase more among women and children living in poverty than men. This gender and age bias in the poverty results is particularly strong for individuals in rural areas, femaleheaded and Black households. It can be shown also that those results are robust for a wide range of poverty lines.

\section{CONCLUSIONS}

South Africa is in the midst of an ambitious trade liberalization program, notably in the context of various regional and international trade agreements. These policies are likely to have wide-ranging effects on the South African economy, in particular its international trade, production, government revenues, factor markets, household incomes and consumer price structure. To analyze the

poverty impacts on South African men, women and children, we construct a CGE microsimulation model including 4,000 actual households from a nationally representative household survey and featuring the explicit modeling of male and female market and domestic work activities and leisure time.

South Africa has a very discriminatory tariff structure with rates varying from 0 to 112.8 percent. The high protection sectors are predominantly comprised of light manufacturing activities such as garments, beverages and tobacco, structural metal, electrical equipment and household appliances. These sectors are found to suffer from a contraction in output and value-added prices subsequent to trade liberalization. In contrast, export-oriented sectors such as mining, transport and communication equipment, machinery and medical instruments expand as a result of the import-driven exchange rate depreciation and the fall in input costs.

As male workers tend to be more heavily involved in export-oriented sectors, whereas women work more in the highly protected light manufacturing activities and services, male wage rates rise with respect to female wage rates. 
An interesting contrast emerges between urban and rural workers. While urban wage rates tend to perform better than rural wage rates, results vary substantially between skill categories. Medium- and urban low-skilled workers, especially men, are the big winners from our trade experiment. In contrast, highand rural low-skilled, and child workers fare worse as a result of their dependency on wages from the agricultural sector in rural areas, and from social services in urban areas. Consequently, wage effects are in favor of the more skilled workers in rural areas and in favor of the less skilled urban workers. As capital is assumed to be immobile in the short run, rates of return closely mirror the evolutions in sectoral value-added prices. The upshot of all these changes is an increase in the incomes of urban and male-headed households relative to their rural and female-headed counterparts. These results compound with a greater reduction in consumer prices among urban and male-headed households to generate for them a smaller increase in poverty and a reduction in inequality.

\section{NOTES}

1. Elson and Pearson (1981), Standing (1989), Cagatay and Ozler (1995), Joekes (1995, 1999) and Ozler (2000, 2001).

2. Gladwin (1991) and Fontana, Joekes, and Masika (1998).

3. Fontana and Wood (2000), Fontana (2001, 2002) for Bangladesh and Zambia; Fofana, Cockburn, and Decaluwe (2003, 2005) for Nepal; and Siddiqui (2004) for Pakistan.

4. Haddad, Brown, Richter, and Smith (1995), Cagatay, Elson and Grown (1995) and Palmer (1994).

5. Elson (1995), Sinha (1999, 2000) and Fofana et al. (2003).

6. Latigo and Ironmonger (2004).

7. The year 2000 Income and Expenditure Survey (IES) is based on the same sample of households as the September 2000 Labor Force Survey (LFS: 2).

8. We observe some complementarity between market and non-market productive activities.

9. Gronau (1977) and Solberg and Wong (1992) assume that home goods are perfect substitutes for market goods. However, in other versions of Gronau's model, these goods are imperfect substitutes. For other assumptions to simplify the modeling aspects, see Fofana et al. (2003).

10. Domestic paid labor, capital goods and intermediate goods are included in the household utility function and indirectly substitute to domestic unpaid labor which is referred here as home goods.

11. We assume that there are very limited substitution possibilities between men and women in the production of home goods, reflected by a low elasticity of substitution (0.5) between male and female domestic work.

12. For details on technical aspect, refer to Fofana et al. (2003). 


\section{ACKNOWLEDGMENTS}

The contribution of both Dr. Alfred Latigo and Mr. Omar Abdourahaman from the ACGD/Economic Commission for Africa in providing comments for this study is greatly appreciated. However, the opinion expressed in this paper is the only responsibility of the authors without engaging the ACGD or the Economic Commission of Africa.

\section{REFERENCES}

Baden, S., Hasim, S., \& Meintjes, S. (1998). Country gender profile: South Africa. Report prepared for the Swedish International Development Office, Pretoria, Republic of South Africa, Bridge Report no. 45.

Budlender, D. (1995). Women and the labor market paper for ILO DRAFT mimeo.

Budlender, D. (Ed.). (1997). Women and men in South Africa. Statistical booklet prepared for the Central Statistical Services (mimeo).

Cagatay, N., Elson, D., \& Grown, C. (1995). Introduction. World Development, 23(11), $1827-1836$.

Cagatay, N., \& Ozler, S. (1995). Feminization of the labor force: The effects of long-term economic development and structural adjustment. World Development, 23(8), 1883-1894.

Casale, D., \& Posel, D. (2002). The continued feminization of the labor force in South Africa: An analysis of recent data and trends. The South African Journal of Economics. [Die Suid-Afrikaanse Tydskrif vir Ekonomie J, 70, 1 March-Maart 2002.

Crankshaw, O. (1997). Race, class and the changing division of labor under apartheid. London: Routledge.

Davies, R., \& van Seventer, D. (2003). A gap and macro decomposition analysis for South Africa, 1993-2002. Development Policy Research Unit, School of Economics, University of Cape Town.

Decaluwe, B., Martens, A., \& Savard, L. (2001). La politique économique du développement et les modeles d'équilibre général calculable. Presses de l'Université de Montréal, Montreal, Canada.

Elson, D. (1995). Gender awareness in modeling structural adjustment. World Development, 23(11), 1851-1868.

Elson, D., \& Pearson, R. (1981). Nimble fingers make cheap workers. Feminist Review, 7 , $87-107$.

Fallon, P., \& Lucas, R. (1998). South African labor markets. Adjustment and inequalities. Discussion Paper no. 12. World Bank, Southern Africa Department, Washington.

Fofana, I., Cockburn, J., \& Decaluwe, B. (2003). Modeling male and female work in a computable general equilibrium. CIRPÉE, Université Laval, Québec, Canada (mimeo).

Fofana, I., Cockburn, J., \& Decaluwe, B. (2005). Developing country superwomen: Impact of trade liberalization on female market and domestic work. Working Paper 05-19. CIRPEE, University Laval.

Fontana, M. (2001). Modeling the effects of trade on women: A closer look at Bangladesh. Working Paper 139. Institute of Development Studies, Brighton. 
Fontana, M. (2002). Modeling the effects of trade on women: The case of Zambia. Working Paper 155. Institute of Development Studies, Brighton.

Fontana, M., Joekes, S., \& Masika, R. (1998). Global trade expansion and liberalization: Gender issue and impacts. Bridge Report no. 42. IDS, Brighton, UK.

Fontana, M., \& Wood, A. (2000). Modeling the effects of trade on women at work and at home. World Development, 28(7), 1173-1190.

Gladwin, C. (1991). Structural adjustment and the African women farmers. Economic performance in Latin America and the Caribbean. New York: Oxford.

Gronau, R. (1977). Leisure, home production, and work - The theory of the allocation of time revised. Journal of Political Economy, 85(6), 1099-1124.

Haddad, L., Brown, L. R., Richter, A., \& Smith, L. (1995). The gender dimensions of economic adjustment policies: Potential interactions and evidence to date. World Development, 23(6), 881-896.

Hofmeyr, J. F. (1993). African wage movements in the 1980s. South African Journal of Economics, 61(4), 266-280.

Hoogeveen, J. G., \& Özler, B. (2004). Not separate, not equal poverty and inequality in postapartheid South Africa. World Bank, 1818 H Street NW, Washington, DC 20433, USA.

ILO. (1999). ILO report on social impact of globalization. Geneva: ILO.

Joekes, S. (1995). Trade-related employment for women in industry and services in developing countries. UNRISD Occasional Paper, Geneva.

Joekes, S. (1999). A gender-analytical perspective on trade and sustainable development. In: UNCTAD, Trade sustainable development and gender. New York and Geneva: UNCTAD.

Klasen, S., \& Woolard, J. (1998). Levels, trends and consistency of employment and unemployment figures in South Africa. Working Paper, unpublished. University of Munich/ University of Port Elizabeth.

Latigo, A., \& Ironmonger, D. (2004). The missing link in growth and sustainable development: Closing the gender gap. An Issues Paper presented at the ADB/ECA Symposium of African Ministers of Finance, Planning and Economic Development, 24 May 2004, Kampala, Uganda.

Lewis, J. (2001). Reform and opportunity: The changing role and patterns of trade in South Africa and SADC. Africa Region Working Paper Series no. 14. The World Bank, Washington, DC.

Ndlela, T., \& Nkala, P. (2003). Determinants of exports from SADC and the role of market access. Paper presented at the Trade and Industrial Policy Strategies (TIPS), 2003 Annual Forum at Glenburn Lodge, Muldersdrift.

Ozler, S. (2000). Export orientation and female share of employment: The evidence from Turkey. World Development, 28(7), 1239-1248.

Ozler, S. (2001). Export led industrialization and gender differences in job creation and destruction: Micro evidence from the Turkish manufacturing sector. Unpublished paper, Department of Economics, UCLA.

Palmer, I. (1994). Social and gender issues in macro-economic policy advice. Social Policy Series no. 13. GTZ, Eschborn.

Rospabe, S. (2002). An evaluation of gender discrimination in employment, occupation attainment and wage in South Africa in the late 1990s. Development Policy Research Institute, University of Cape Town, mimeo. 
Siddiqui, R. (2004). Modelling gender dimensions of the impact of economic reforms on time allocation among market work, households work and leisure. Research Report no. 185. Pakistan Institute of Development Economics, Islamabad, Pakistan.

Sinha, A. (1999). Gender awareness in macroeconomic analysis. An Indian experiment presented at the conference on Feminist Economics at Calton University, Ottawa, Canada.

Sinha, A. (2000). Gender in macroeconomic framework, a CGE model analysis. Presented at the 2nd Annual Gender Planning Network Meeting, Kathmandu.

Solberg, J. E., \& Wong, D. C. (1992). Family time use: Leisure, home production, market work, and work related travel. The Journal of Human Resources, 27(3), 485-510.

Standing, G. (1989). Global feminization through flexible labor. World Development, 17(7), $1077-1095$.

Standing, G., Sender, J., \& Weeks, J. (1996). Restructuring the labor market: The South African challenge. An ILO country review. Geneva: ILO.

Statistics South Africa. (1999). October household survey South Africa.

Statistics South Africa. (2001a). Labor force survey. February 2001 Statistical release P0210.

Statistics South Africa. (2001b). A survey of time use: How South African women and men spend their time. Pretoria, South Africa.

TIPS. (2002). A review of the changing composition of the South African economy. Report compiled by Trade and Industrial Policy Strategies.

United Nations Development Programme. (UNDP). (2000). Human development report 1997. New York, USA.

Valodia, I. (1996). Work, Chapter 3. In: D. Budlender, (Ed.), The women's budget (pp. 53-96). Cape Town: IDASA.

Valodia, I. (2000). Economic policy and women's informal and flexible work in South Africa. Paper presented at the Tips 2000 Annual Forum.

World Bank. (1999). South Africa country assistance strategy: Building a knowledge partnership. The World Bank Group, Africa Region, Washington.

World Bank. (2002). Gender stats - Database for gender statistics. http://devdata.worldbank. org/genderstats

World Bank. (2004). World development. http://devdata.worldbank.org 
APPENDIX 1. TRADE AND OUTPUT EFFECTS

\begin{tabular}{|c|c|c|c|c|c|c|c|c|c|c|c|c|c|}
\hline \multirow[t]{2}{*}{ Sectors } & \multirow[t]{2}{*}{ Tariff } & \multicolumn{3}{|c|}{ Sectoral Shares } & \multirow[t]{2}{*}{ IPR } & \multirow[t]{2}{*}{ EIR } & \multicolumn{4}{|c|}{ Volume Changes } & \multicolumn{3}{|c|}{ Price Changes } \\
\hline & & VA & $\operatorname{Imp}$ & $\operatorname{Exp}$ & & & $\operatorname{Imp}$ & $\operatorname{Exp}$ & Output & Dom & $\operatorname{Imp}$ & Dom & Output \\
\hline AGRICULTURE & 1.1 & 3.3 & 1.6 & 2.6 & 7.0 & 12.4 & -5.9 & 2.9 & -0.5 & -1.0 & 3.7 & 0.3 & 0.6 \\
\hline Gold and uranium & 0.0 & 2.1 & 0.0 & 9.9 & 0.0 & 85.3 & -5.8 & 0.0 & 0.0 & 0.0 & 4.9 & 0.8 & 0.8 \\
\hline Other mining & 0.0 & 4.7 & 13.7 & 24.8 & 73.0 & 87.5 & -0.4 & 0.0 & 0.4 & 2.7 & 4.9 & 2.8 & 1.3 \\
\hline MINING $^{\mathrm{a}}$ & 0.0 & 6.8 & 13.7 & 34.7 & 65.8 & 86.8 & -0.4 & 0.0 & 0.3 & 1.9 & 4.9 & 2.2 & 1.2 \\
\hline Meat and vegetables & 4.0 & 0.5 & 1.5 & 1.8 & 11.9 & 16.4 & -1.6 & 2.6 & -0.8 & -1.1 & 0.9 & 0.6 & 0.8 \\
\hline Dairy & 7.6 & 0.2 & 0.2 & 0.2 & 6.1 & 6.8 & 3.6 & 2.7 & -1.0 & -1.1 & -2.5 & 0.6 & 0.6 \\
\hline Grain milling & 3.2 & 0.4 & 0.6 & 0.3 & 9.1 & 4.5 & -2.8 & 2.6 & -1.1 & -1.2 & 1.6 & 0.5 & 0.6 \\
\hline Other food & 5.5 & 0.8 & 0.5 & 1.2 & 6.4 & 16.8 & -0.3 & 2.7 & -1.0 & -1.5 & -0.6 & 0.2 & 0.6 \\
\hline Beverages and tobacco & 112.8 & 1.4 & 0.4 & 1.6 & 3.4 & 14.1 & 147.7 & 5.3 & -4.9 & -5.9 & -50.7 & -6.0 & -5.4 \\
\hline Textiles & 6.7 & 0.2 & 1.0 & 0.4 & 28.7 & 17.4 & 0.4 & 2.1 & -1.9 & -2.5 & -1.7 & 0.2 & 0.7 \\
\hline Garments & 17.2 & 0.7 & 1.5 & 1.1 & 18.0 & 18.5 & 14.8 & 2.0 & -2.7 & -2.9 & -10.5 & 0.1 & 0.3 \\
\hline Leather & 1.9 & 0.1 & 0.4 & 0.5 & 40.2 & 47.7 & -2.3 & 3.4 & 1.9 & 0.7 & 3.0 & 0.9 & 1.6 \\
\hline Footwear & 11.7 & 0.1 & 0.7 & 0.1 & 34.8 & 8.4 & 7.3 & 2.5 & -2.1 & -2.3 & -6.1 & 0.0 & 0.1 \\
\hline Wood & 0.9 & 0.5 & 0.6 & 0.8 & 13.2 & 19.3 & -4.1 & 3.7 & 1.4 & 0.9 & 4.0 & 0.5 & 0.9 \\
\hline Paper & 7.7 & 0.9 & 1.3 & 2.4 & 12.6 & 24.3 & 3.8 & 3.2 & 0.2 & -0.6 & -2.6 & 0.2 & 0.8 \\
\hline Printing & 1.9 & 0.7 & 1.1 & 0.4 & 17.0 & 7.4 & -2.8 & 3.5 & 0.8 & 0.6 & 2.9 & 0.6 & 0.7 \\
\hline Petroleum & 0.7 & 1.5 & 1.1 & 3.4 & 7.5 & 24.3 & -5.2 & 2.1 & -0.5 & -1.0 & 4.2 & 1.3 & 1.6 \\
\hline Basic chemicals & 1.2 & 1.0 & 5.2 & 3.7 & 39.2 & 34.6 & -1.0 & 2.3 & 1.4 & 0.9 & 3.7 & 2.4 & 2.7 \\
\hline Other chemicals & 1.4 & 1.2 & 5.4 & 1.8 & 28.8 & 13.8 & -2.6 & 2.4 & 0.3 & 0.0 & 3.5 & 1.6 & 1.8 \\
\hline Rubber products & 6.4 & 0.2 & 0.9 & 0.4 & 32.4 & 22.0 & 2.4 & 2.3 & -0.6 & -1.2 & -1.4 & 1.0 & 1.4 \\
\hline Plastic products & 1.4 & 0.6 & 1.0 & 0.3 & 18.9 & 7.9 & -2.6 & 2.7 & 0.5 & 0.3 & 3.4 & 1.4 & 1.5 \\
\hline Glass products & 1.5 & 0.1 & 0.3 & 0.2 & 24.8 & 16.3 & -2.8 & 3.0 & 0.8 & 0.5 & 3.4 & 1.1 & 1.3 \\
\hline Non-metallic mineral & 1.5 & 0.6 & 1.1 & 0.4 & 17.8 & 7.7 & -1.7 & 2.4 & 0.5 & 0.4 & 3.3 & 1.9 & 2.0 \\
\hline
\end{tabular}




\begin{tabular}{|c|c|c|c|c|c|c|c|c|c|c|c|c|c|}
\hline Iron and steel & 0.5 & 2.2 & 3.1 & 10.5 & 17.2 & 46.1 & -1.2 & 2.1 & 1.5 & 1.1 & 4.4 & 2.8 & 3.1 \\
\hline Structural metal & 20.7 & 0.4 & 0.1 & 0.4 & 2.5 & 11.7 & 25.2 & 2.2 & -0.4 & -0.8 & -13.1 & 1.4 & 1.7 \\
\hline Other fabricated metal & 2.2 & 0.8 & 1.8 & 0.7 & 20.3 & 10.0 & -0.9 & 2.6 & 0.6 & 0.4 & 2.6 & 1.7 & 1.8 \\
\hline General purpose machinery & 2.2 & 0.4 & 4.3 & 2.6 & 72.2 & 71.4 & -0.3 & 4.0 & 3.3 & 2.1 & 2.6 & 1.0 & 1.8 \\
\hline Special purpose machinery & 2.7 & 0.4 & 5.8 & 1.4 & 60.7 & 32.9 & -0.4 & 3.0 & 1.4 & 0.8 & 2.2 & 1.4 & 1.8 \\
\hline Household appliances & 10.6 & 0.1 & 0.5 & 0.1 & 35.8 & 14.1 & 5.5 & 1.8 & -2.7 & -3.1 & -5.1 & 0.4 & 0.6 \\
\hline Electric motors & 7.2 & 0.1 & 0.6 & 0.2 & 42.9 & 25.4 & 2.0 & 2.5 & -0.7 & -1.7 & -2.1 & 0.3 & 1.0 \\
\hline Electricity distribution & 0.7 & 0.1 & 0.9 & 0.2 & 56.9 & 20.3 & -1.4 & 3.2 & 2.2 & 1.9 & 4.2 & 1.9 & 2.1 \\
\hline Insulated wire and cable & 14.9 & 0.1 & 0.2 & 0.1 & 11.9 & 6.4 & 12.8 & 1.9 & -2.2 & -2.4 & -8.7 & 0.6 & 0.8 \\
\hline Accumulators & 1.3 & 0.1 & 0.2 & 0.1 & 27.0 & 12.8 & -2.6 & 2.8 & 0.7 & 0.4 & 3.5 & 1.4 & 1.6 \\
\hline Lighting equipment & 1.5 & 0.0 & 0.3 & 0.0 & 39.8 & 11.5 & -1.9 & 3.2 & 1.2 & 1.0 & 3.3 & 1.3 & 1.4 \\
\hline Other electrical equipment & 10.5 & 0.2 & 0.7 & 0.4 & 28.9 & 23.6 & 6.0 & 2.4 & -1.6 & -2.2 & -5.0 & 0.2 & 0.6 \\
\hline Communication equipment & 2.6 & 0.2 & 6.1 & 0.7 & 77.8 & 33.7 & -0.8 & 3.4 & 1.7 & 1.0 & 2.3 & 1.1 & 1.5 \\
\hline Medical instruments & 0.5 & 0.1 & 3.0 & 0.4 & 83.5 & 57.9 & -0.8 & 3.9 & 3.4 & 3.2 & 4.4 & 1.7 & 1.8 \\
\hline Motor vehicles & 5.7 & 0.9 & 4.9 & 3.8 & 23.4 & 21.2 & 2.1 & 1.6 & -0.9 & -1.5 & -0.8 & 1.6 & 2.1 \\
\hline Motor vehicle parts & 0.0 & 0.5 & 8.5 & 1.2 & 64.6 & 23.3 & -1.7 & 2.9 & 2.1 & 2.0 & 4.9 & 2.3 & 2.4 \\
\hline Other transport equipment & 0.0 & 0.1 & 3.6 & 1.1 & 85.1 & 69.0 & -0.3 & 3.4 & 3.3 & 3.2 & 4.9 & 2.5 & 2.6 \\
\hline Furniture & 7.0 & 0.3 & 0.3 & 1.1 & 11.3 & 39.9 & 3.0 & 2.6 & -0.7 & -1.0 & -2.0 & 0.7 & 0.9 \\
\hline Other manufacturing & 2.4 & 0.2 & 5.4 & 1.8 & 75.1 & 68.5 & -0.7 & 2.2 & 1.0 & 0.0 & 2.5 & 2.0 & 2.6 \\
\hline INDUSTRY ${ }^{\mathrm{a}}$ & 3.3 & 18.8 & 74.9 & 47.7 & 29.4 & 24.1 & 0.6 & 2.6 & -0.1 & -0.7 & 1.5 & 0.8 & 1.3 \\
\hline Electricity and gas & 0.0 & 2.4 & 0.0 & 0.4 & 0.0 & 3.6 & 0.0 & 2.9 & -0.1 & -0.3 & 0.0 & 0.8 & 0.8 \\
\hline Water & 0.0 & 0.4 & 0.0 & 0.0 & 0.2 & 0.4 & -6.9 & 3.0 & -0.6 & -0.6 & 4.9 & 0.4 & 0.4 \\
\hline Building & 0.0 & 1.6 & 0.1 & 0.0 & 0.5 & 0.1 & -5.0 & 2.6 & 0.0 & 0.0 & 4.9 & 1.4 & 1.4 \\
\hline Construction & 0.0 & 1.3 & 0.2 & 0.0 & 1.9 & 0.2 & -5.4 & 2.6 & -0.2 & -0.2 & 4.9 & 1.3 & 1.3 \\
\hline Trade services & 0.0 & 11.1 & 0.1 & 0.2 & 0.1 & 0.3 & -5.7 & 3.2 & 0.2 & 0.2 & 4.9 & 0.8 & 0.8 \\
\hline Hotel and restaurant & 0.0 & 2.0 & 2.0 & 2.6 & 20.6 & 27.4 & -5.6 & 3.0 & 0.9 & 0.1 & 4.9 & 0.9 & 1.4 \\
\hline Transport services & 0.0 & 6.2 & 2.8 & 5.2 & 7.6 & 14.5 & -4.7 & 2.7 & 0.6 & 0.2 & 4.9 & 1.4 & 1.7 \\
\hline Post and telecommunications & 0.0 & 3.9 & 1.6 & 1.1 & 6.6 & 5.1 & -5.4 & 3.0 & 0.3 & 0.2 & 4.9 & 1.0 & 1.1 \\
\hline Financial services & 0.0 & 10.0 & 0.8 & 2.9 & 1.4 & 5.5 & -7.2 & 3.4 & -0.2 & -0.4 & 4.9 & 0.1 & 0.2 \\
\hline
\end{tabular}


APPENDIX 1. (Continued)

\begin{tabular}{|c|c|c|c|c|c|c|c|c|c|c|c|c|c|}
\hline \multirow[t]{2}{*}{ Sectors } & \multirow[t]{2}{*}{ Tariff } & \multicolumn{3}{|c|}{ Sectoral Shares } & \multirow[t]{2}{*}{ IPR } & \multirow[t]{2}{*}{ EIR } & \multicolumn{4}{|c|}{ Volume Changes } & \multicolumn{3}{|c|}{ Price Changes } \\
\hline & & VA & Imp & $\operatorname{Exp}$ & & & $\operatorname{Imp}$ & Exp & Output & Dom & $\operatorname{Imp}$ & Dom & Output \\
\hline Real estate & 0.0 & 6.0 & 0.2 & 0.4 & 0.6 & 1.5 & -5.6 & 3.0 & 0.1 & 0.0 & 4.9 & 0.9 & 0.9 \\
\hline Other business & 0.0 & 2.9 & 1.0 & 0.6 & 5.5 & 3.4 & -5.5 & 3.2 & 0.4 & 0.3 & 4.9 & 0.8 & 0.9 \\
\hline General government & 0.0 & 16.5 & 0.0 & 0.5 & 0.0 & 0.7 & 0.0 & 3.3 & 0.0 & 0.0 & 0.0 & 0.5 & 0.5 \\
\hline Health and social work & 0.0 & 1.9 & 0.1 & 0.3 & 0.6 & 2.6 & -6.7 & 2.7 & -0.7 & -0.8 & 4.9 & 0.7 & 0.8 \\
\hline Other services & 0.0 & 4.8 & 0.9 & 0.8 & 4.0 & 4.0 & -6.7 & 3.2 & -0.2 & -0.3 & 4.9 & 0.4 & 0.5 \\
\hline SERVICE $^{\mathrm{a}}$ & 0.0 & 71.1 & 9.8 & 15.0 & 3.1 & 4.0 & -5.6 & 3.0 & 0.1 & -0.1 & 4.9 & 0.7 & 0.8 \\
\hline $\mathrm{ALL}^{\mathrm{a}}$ & 2.5 & 100.0 & 100.0 & 100.0 & 16.1 & 15.8 & -0.3 & 1.8 & 0.0 & -0.3 & 2.3 & 0.7 & 1.0 \\
\hline
\end{tabular}

Notes: VA = value added; Imp = imports; Exp = exports; Dom = local sales of domestic output; IPR = import penetration ratio; EIR = export intensity ratio.

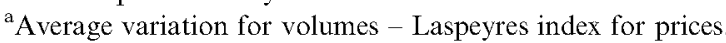


APPENDIX 2. FACTOR EFFECTS

\begin{tabular}{|c|c|c|c|c|c|c|c|c|c|c|c|c|c|c|c|c|c|c|c|}
\hline \multirow[t]{3}{*}{ Sectors } & \multirow[t]{3}{*}{ VA Price } & \multicolumn{8}{|c|}{ Share in Male Wages } & \multicolumn{8}{|c|}{ Share in Female Wages } & \multicolumn{2}{|c|}{ Capital } \\
\hline & & \multicolumn{4}{|c|}{ Urban } & \multicolumn{4}{|c|}{ Rural } & \multicolumn{4}{|c|}{ Urban } & \multicolumn{4}{|c|}{ Rural } & \multirow[t]{2}{*}{ Share } & \multirow[t]{2}{*}{ Returns } \\
\hline & & Hi & Med & Lo & Kid & $\mathrm{Hi}$ & Med & Lo & Kid & $\mathrm{Hi}$ & Med & Lo & Kid & $\mathrm{Hi}$ & Med & Lo & Kid & & \\
\hline GRICULTURE & -1.0 & 0.1 & 1.1 & 4.6 & 50.6 & 14.2 & 13.4 & 33.3 & 75.8 & 0.4 & 0.5 & 2.4 & 88.2 & 1.7 & 8.3 & 20.1 & 100.0 & 4.8 & -1.5 \\
\hline Gold and uranium & 0.0 & 1.8 & 5.8 & 5.4 & 0.0 & 0.0 & 0.8 & 0.2 & 0.0 & 0.2 & 0.2 & 0.1 & 0.0 & 0.0 & 0.0 & 0.0 & 0.0 & 1.4 & 0.0 \\
\hline Other mining & 0.7 & 2.2 & 5.1 & 2.3 & 0.0 & 2.9 & 11.6 & 7.3 & 0.0 & 0.3 & 0.5 & 0.3 & 0.0 & 0.0 & 2.7 & 0.1 & 0.0 & 6.5 & 1.2 \\
\hline MINING & 0.5 & 4.0 & 11.0 & 7.7 & 0.0 & 2.9 & 12.3 & 7.5 & 0.0 & 0.5 & 0.7 & 0.4 & 0.0 & 0.0 & 2.7 & 0.1 & 0.0 & 7.9 & 1.0 \\
\hline Meat and vegetables & -0.5 & 0.4 & 0.5 & 1.3 & 0.0 & 0.6 & 0.4 & 1.0 & 0.0 & 0.2 & 0.5 & 2.1 & 0.0 & 1.3 & 0.9 & 0.7 & 0.0 & 0.5 & -1.3 \\
\hline Dairy & -0.5 & 0.3 & 0.5 & 0.5 & 0.0 & 0.7 & 0.0 & 0.2 & 0.0 & 0.0 & 0.0 & 0.0 & 0.0 & 0.0 & 0.0 & 0.2 & 0.0 & 0.2 & -1.5 \\
\hline Grain milling & -1.2 & 0.5 & 0.2 & 0.5 & 0.0 & 0.4 & 0.3 & 0.3 & 0.0 & 0.2 & 0.1 & 0.1 & 0.0 & 0.0 & 0.6 & 0.1 & 0.0 & 0.4 & -2.3 \\
\hline Other food & -0.7 & 0.4 & 0.9 & 2.8 & 0.0 & 0.3 & 1.5 & 1.4 & 0.0 & 0.1 & 0.9 & 1.4 & 0.0 & 0.0 & 1.2 & 2.3 & 0.0 & 0.7 & -1.6 \\
\hline Beverages and tobacco & -11.4 & 1.7 & 0.4 & 1.0 & 0.0 & 0.1 & 0.4 & 0.4 & 0.0 & 0.3 & 0.3 & 0.1 & 0.7 & 0.0 & 0.8 & 0.2 & 0.0 & 2.2 & -15.8 \\
\hline Textiles & -0.6 & 0.1 & 0.3 & 0.7 & 0.0 & 0.0 & 0.3 & 0.0 & 0.0 & 0.1 & 0.9 & 0.2 & 0.0 & 0.0 & 0.7 & 0.0 & 0.0 & 0.1 & -2.4 \\
\hline Garments & -0.5 & 0.5 & 0.6 & 1.4 & 0.0 & 0.1 & 0.3 & 0.3 & 0.0 & 1.2 & 3.9 & 2.4 & 0.0 & 0.7 & 7.2 & 0.9 & 0.0 & 0.2 & -3.1 \\
\hline Leather & 1.3 & 0.1 & 0.1 & 0.0 & 0.0 & 0.0 & 0.1 & 0.2 & 0.0 & 0.1 & 0.1 & 0.2 & 0.0 & 0.0 & 0.0 & 0.1 & 0.0 & 0.1 & 3.3 \\
\hline Footwear & -2.0 & 0.0 & 0.2 & 0.0 & 0.0 & 0.0 & 0.0 & 0.0 & 0.0 & 0.0 & 0.3 & 0.3 & 0.0 & 0.0 & 0.7 & 0.1 & 0.0 & 0.1 & -4.1 \\
\hline Wood & 0.5 & 0.2 & 1.0 & 1.0 & 0.0 & 0.3 & 1.8 & 1.9 & 0.0 & 0.2 & 0.4 & 0.2 & 0.0 & 0.0 & 1.2 & 1.0 & 0.0 & 0.3 & 1.9 \\
\hline Paper & 0.3 & 0.5 & 1.0 & 0.6 & 0.0 & 0.0 & 0.4 & 0.4 & 0.0 & 1.0 & 0.6 & 0.9 & 0.0 & 0.0 & 0.4 & 1.6 & 0.0 & 1.1 & 0.5 \\
\hline Printing & 0.3 & 1.1 & 0.9 & 1.2 & 7.2 & 0.0 & 0.2 & 0.2 & 0.0 & 1.7 & 1.1 & 0.5 & 0.0 & 1.0 & 0.4 & 0.0 & 0.0 & 0.4 & 1.0 \\
\hline Petroleum & -2.9 & 0.8 & 0.5 & 0.1 & 0.0 & 0.0 & 0.1 & 0.0 & 0.0 & 0.1 & 0.0 & 0.0 & 0.0 & 0.0 & 0.0 & 0.0 & 0.0 & 2.7 & -3.4 \\
\hline Basic chemicals & 2.2 & 1.2 & 0.6 & 0.2 & 0.0 & 1.9 & 0.4 & 0.0 & 0.0 & 0.3 & 0.3 & 0.1 & 0.0 & 0.0 & 0.0 & 0.0 & 0.0 & 1.3 & 3.6 \\
\hline Other chemicals & 0.1 & 3.0 & 0.4 & 1.4 & 0.0 & 0.0 & 0.6 & 0.5 & 0.0 & 1.9 & 0.4 & 2.8 & 0.0 & 0.0 & 0.7 & 0.2 & 0.0 & 0.9 & 0.4 \\
\hline Rubber products & -0.2 & 0.1 & 0.6 & 0.0 & 0.0 & 0.0 & 0.5 & 0.0 & 0.0 & 0.0 & 0.1 & 0.0 & 0.0 & 0.0 & 0.0 & 0.1 & 0.0 & 0.1 & -0.8 \\
\hline Plastic products & 0.1 & 0.7 & 0.9 & 1.5 & 0.0 & 0.2 & 0.0 & 0.1 & 0.0 & 0.7 & 1.2 & 3.6 & 0.0 & 0.0 & 0.2 & 1.0 & 0.0 & 0.1 & 0.5 \\
\hline Glass products & 0.4 & 0.1 & 0.3 & 0.4 & 0.0 & 0.0 & 0.2 & 0.0 & 0.0 & 0.0 & 0.1 & 0.0 & 0.0 & 0.0 & 0.1 & 0.0 & 0.0 & 0.1 & 1.2 \\
\hline Non-metallic mineral & 0.9 & 0.5 & 0.5 & 0.3 & 0.0 & 0.1 & 0.8 & 0.6 & 0.0 & 0.1 & 0.1 & 0.3 & 0.0 & 0.0 & 0.8 & 0.2 & 0.0 & 0.9 & 1.5 \\
\hline Iron and steel & 2.9 & 1.0 & 1.9 & 3.5 & 0.0 & 0.8 & 1.4 & 0.3 & 0.0 & 1.2 & 1.1 & 0.1 & 0.0 & 0.0 & 0.2 & 0.0 & 0.0 & 3.2 & 4.5 \\
\hline
\end{tabular}


APPENDIX 2. (Continued)

\begin{tabular}{|c|c|c|c|c|c|c|c|c|c|c|c|c|c|c|c|c|c|c|c|}
\hline \multirow[t]{3}{*}{ Sectors } & \multirow[t]{3}{*}{ VA Price } & \multicolumn{8}{|c|}{ Share in Male Wages } & \multicolumn{8}{|c|}{ Share in Female Wages } & \multicolumn{2}{|c|}{ Capital } \\
\hline & & \multicolumn{4}{|c|}{ Urban } & \multicolumn{4}{|c|}{ Rural } & \multicolumn{4}{|c|}{ Urban } & \multicolumn{4}{|c|}{ Rural } & \multirow[t]{2}{*}{ Share } & \multirow[t]{2}{*}{ Returns } \\
\hline & & $\mathrm{Hi}$ & Med & Lo & Kid & $\mathrm{Hi}$ & Med & Lo & Kid & $\mathrm{Hi}$ & Med & Lo & Kid & $\mathrm{Hi}$ & Med & Lo & Kid & & \\
\hline Structural metal & -0.1 & 0.3 & 1.0 & 0.5 & 0.0 & 0.7 & 0.6 & 0.0 & 0.0 & 0.0 & 0.1 & 0.0 & 0.0 & 0.0 & 0.0 & 0.0 & 0.0 & 0.2 & -0.5 \\
\hline Other fabricated metal & 0.4 & 1.2 & 1.0 & 1.4 & 0.0 & 0.0 & 0.3 & 0.1 & 0.0 & 1.3 & 0.1 & 0.0 & 0.0 & 0.2 & 0.6 & 0.1 & 0.0 & 0.6 & 1.0 \\
\hline General purpose machinery & 0.6 & 0.6 & 0.5 & 1.2 & 0.0 & 0.0 & 0.0 & 0.2 & 0.0 & 0.2 & 1.2 & 0.0 & 0.0 & 0.0 & 0.0 & 0.3 & 0.0 & 0.1 & 3.9 \\
\hline Special purpose machinery & 0.4 & 1.0 & 0.7 & 0.9 & 0.0 & 0.0 & 0.8 & 0.0 & 0.0 & 0.1 & 0.2 & 0.0 & 0.0 & 0.0 & 0.0 & 0.2 & 0.0 & 0.2 & 1.7 \\
\hline Household appliances & -0.8 & 0.1 & 0.1 & 0.1 & 0.0 & 0.2 & 0.0 & 0.0 & 0.0 & 0.2 & 0.0 & 0.2 & 0.0 & 0.0 & 0.0 & 0.1 & 0.0 & 0.0 & -3.5 \\
\hline Electric motors & -0.2 & 0.2 & 0.1 & 0.0 & 0.0 & 0.0 & 0.0 & 0.0 & 0.0 & 0.0 & 0.3 & 0.0 & 0.0 & 0.0 & 0.0 & 0.0 & 0.0 & 0.0 & -1.0 \\
\hline Electricity distribution & 2.6 & 0.0 & 0.2 & 0.0 & 0.0 & 0.0 & 0.0 & 0.0 & 0.0 & 0.0 & 0.1 & 0.1 & 0.0 & 0.0 & 0.0 & 0.0 & 0.0 & 0.1 & 4.8 \\
\hline Insulated wire and cable & -3.0 & 0.1 & 0.2 & 0.0 & 0.0 & 0.0 & 0.0 & 0.6 & 0.0 & 0.0 & 0.1 & 0.1 & 0.0 & 0.0 & 0.3 & 0.0 & 0.0 & 0.2 & -5.1 \\
\hline Accumulators & 0.7 & 0.0 & 0.1 & 0.0 & 0.0 & 0.0 & 0.0 & 0.0 & 0.0 & 0.0 & 0.0 & 1.1 & 0.0 & 0.0 & 0.0 & 0.0 & 0.0 & 0.1 & 1.4 \\
\hline Lighting equipment & 1.1 & 0.0 & 0.0 & 0.0 & 0.0 & 0.0 & 0.5 & 0.0 & 0.0 & 0.0 & 0.1 & 0.1 & 0.0 & 0.0 & 0.0 & 0.0 & 0.0 & 0.0 & 2.4 \\
\hline Other electrical equipment & -1.3 & 0.4 & 0.1 & 0.0 & 13.8 & 0.0 & 0.0 & 0.0 & 0.0 & 0.0 & 0.2 & 0.1 & 0.0 & 0.0 & 0.4 & 0.1 & 0.0 & 0.2 & -2.9 \\
\hline Communication equipment & 0.7 & 0.2 & 0.0 & 0.0 & 0.0 & 0.0 & 0.0 & 0.0 & 0.0 & 2.0 & 0.1 & 0.1 & 0.0 & 0.0 & 0.0 & 0.0 & 0.0 & 0.1 & 2.4 \\
\hline Medical instruments & 1.3 & 0.1 & 0.0 & 0.1 & 0.0 & 0.0 & 0.0 & 0.0 & 0.0 & 0.0 & 0.4 & 0.1 & 0.0 & 0.0 & 0.0 & 0.0 & 0.0 & 0.0 & 4.7 \\
\hline Motor vehicles & -0.8 & 1.5 & 1.0 & 0.3 & 0.0 & 1.2 & 0.3 & 0.2 & 0.0 & 0.1 & 0.3 & 0.6 & 0.0 & 0.0 & 0.7 & 0.1 & 0.0 & 1.0 & -1.7 \\
\hline Motor vehicle parts & 1.1 & 0.4 & 1.0 & 1.5 & 0.0 & 0.3 & 0.8 & 0.0 & 0.0 & 0.2 & 0.4 & 0.3 & 0.0 & 0.0 & 0.0 & 0.0 & 0.0 & 0.4 & 3.3 \\
\hline Other transport equipment & 0.3 & 0.5 & 0.3 & 0.2 & 0.0 & 0.0 & 0.0 & 0.0 & 0.0 & 0.0 & 0.0 & 0.0 & 0.0 & 0.0 & 0.0 & 0.0 & 0.0 & 0.0 & 3.6 \\
\hline Furniture & -0.2 & 0.4 & 0.4 & 0.7 & 0.0 & 0.0 & 0.7 & 0.2 & 0.0 & 0.0 & 0.3 & 0.0 & 0.0 & 0.0 & 0.1 & 0.4 & 0.0 & 0.2 & -0.9 \\
\hline Other manufacturing & 0.8 & 0.1 & 0.2 & 0.4 & 0.0 & 0.7 & 0.1 & 0.1 & 0.0 & 0.2 & 0.4 & 0.4 & 0.0 & 0.0 & 0.2 & 0.0 & 0.0 & 0.2 & 1.8 \\
\hline INDUSTRY & -0.6 & 20.2 & 19.0 & 25.8 & 21.0 & 8.4 & 13.9 & 9.2 & 0.0 & 13.9 & 16.7 & 18.8 & 0.7 & 3.2 & 18.6 & 9.9 & 0.0 & 19.4 & -2.5 \\
\hline Electricity and gas & -0.3 & 2.3 & 1.8 & 1.0 & 0.0 & 0.0 & 0.7 & 1.4 & 0.0 & 0.4 & 0.9 & 0.7 & 0.0 & 0.0 & 0.3 & 0.0 & 0.0 & 3.5 & -0.4 \\
\hline Water & -1.2 & 0.4 & 0.2 & 0.0 & 0.0 & 0.5 & 0.8 & 1.0 & 0.0 & 0.0 & 0.1 & 0.0 & 0.0 & 0.0 & 1.2 & 0.3 & 0.0 & 0.6 & -1.8 \\
\hline Building & 0.0 & 0.6 & 4.5 & 0.8 & 11.4 & 0.2 & 3.2 & 0.9 & 0.0 & 0.0 & 0.5 & 0.2 & 0.0 & 0.0 & 0.5 & 0.0 & 0.0 & 1.3 & 0.1 \\
\hline Construction & -0.1 & 0.6 & 1.5 & 10.9 & 5.9 & 0.6 & 2.8 & 9.5 & 0.0 & 0.1 & 0.3 & 0.2 & 0.0 & 0.0 & 0.6 & 0.5 & 0.0 & 1.2 & -0.3 \\
\hline Trade services & 0.1 & 8.1 & 12.2 & 16.3 & 2.7 & 9.6 & 13.2 & 7.5 & 24.2 & 9.5 & 16.8 & 19.2 & 2.2 & 6.2 & 24.4 & 15.8 & 0.0 & 10.2 & 0.3 \\
\hline Hotel and restaurant & 2.1 & 0.5 & 0.9 & 0.5 & 0.0 & 0.6 & 1.8 & 0.7 & 0.0 & 1.0 & 2.7 & 1.1 & 0.0 & 0.2 & 5.1 & 1.9 & 0.0 & 3.1 & 3.0 \\
\hline
\end{tabular}


Transport services

$\begin{array}{lllllllllllllllllll}0.7 & 4.6 & 7.4 & 6.0 & 0.0 & 11.6 & 6.0 & 4.5 & 0.0 & 4.3 & 1.8 & 0.6 & 0.0 & 3.3 & 0.3 & 0.3 & 0.0 & 7.5 & 1.2\end{array}$

Post and telecommunications

Financial secom

$\begin{array}{lllllllllllllllllllll}0.5 & 5.0 & 1.5 & 0.9 & 0.0 & 0.3 & 0.2 & 1.2 & 0.0 & 2.1 & 4.8 & 0.3 & 0.0 & 0.1 & 3.2 & 0.9 & 0.0 & 5.2\end{array}$

Real estate

$\begin{array}{llllllllllllllllll}-0.3 & 12.7 & 4.0 & 1.0 & 0.0 & 9.0 & 0.5 & 0.1 & 0.0 & 8.7 & 9.3 & 1.1 & 0.0 & 3.5 & 1.2 & 0.0 & 0.0 & 13.5\end{array}$

Other business

$\begin{array}{llllllllllllllllll}0.8 & 1.7 & 0.1 & 0.5 & 0.0 & 0.3 & 0.0 & 0.0 & 0.0 & 2.0 & 0.5 & 1.0 & 0.0 & 0.0 & 0.0 & 0.0 & 0.0 & 12.4\end{array}$

$\begin{array}{llllllllllllllllll}0.1 & 7.7 & 2.4 & 1.7 & 0.0 & 0.3 & 1.5 & 0.8 & 0.0 & 6.8 & 3.8 & 4.3 & 0.1 & 1.8 & 1.8 & 2.2 & 0.0 & 1.1\end{array}$

General government

Health and social work

$\begin{array}{lllllllllllllllllllll}0.0 & 23.5 & 31.1 & 18.9 & 0.0 & 19.6 & 27.7 & 19.9 & 0.0 & 20.5 & 35.3 & 13.2 & 0.0 & 8.3 & 26.2 & 20.7 & 0.0 & 4.2\end{array}$

Other services

$\begin{array}{llllllllllllllllll}0.6 & 1.4 & 0.3 & 1.1 & 0.0 & 3.3 & 0.4 & 0.8 & 0.0 & 9.0 & 2.0 & 2.8 & 2.1 & 13.3 & 2.3 & 3.0 & 0.0 & 1.9\end{array}$

SERVICES

$\begin{array}{lllllllllllllllllll}-0.1 & 6.4 & 1.1 & 2.3 & 8.3 & 18.8 & 1.4 & 1.9 & 0.0 & 20.9 & 3.2 & 33.8 & 6.8 & 58.3 & 3.5 & 24.4 & 0.0 & 2.3\end{array}$

$\begin{array}{llllllllllllllllll}0.2 & 75.6 & 69.0 & 61.9 & 28.4 & 74.6 & 60.3 & 50.0 & 24.2 & 85.2 & 82.1 & 78.4 & 11.2 & 95.1 & 70.5 & 69.9 & 0.0 & 67.9\end{array}$

ALL $^{\mathrm{a}}$

$\begin{array}{lllllllllllllllll}100 & 100 & 100 & 100 & 100 & 100 & 100 & 100 & 100 & 100 & 100 & 100 & 100 & 100 & 100 & 100 & 100\end{array}$

Notes: VA = value added; Hi, Med, Lo, $\mathrm{Kid}=$ high, medium, low skilled and child workers.

${ }^{a}$ Laspeyres price index 